\title{
Contextualizing Ancestral Pueblo Turkey (Meleagris gallopavo spp.) Management
}

\section{Cyler Conrad $^{1,2}$}

Accepted: 2 July 2021/Published online: 4 August 2021

(C) The Author(s) 2021

\begin{abstract}
Penning turkeys (Meleagris gallopavo spp.) in the Ancestral Pueblo American Southwest/Mexican Northwest (SW/NW) involved the creation or use of a variety of spaces and contexts throughout AD 1-1600 and into the post-contact era. Turkey pens, or captivity, occur through simple tethering, reuse of abandoned pit houses or surface rooms, or creation of pens within villages, plazas, and elsewhere. Turkey dung, droppings, and eggshells are fundamental for determining the presence or absence of pens at archaeological sites. In this paper, I review the archaeological record for turkey pens and focus on three main questions: (1) how are turkey pens identified in the SW/ $\mathrm{NW},(2)$ if turkey pen construction or evidence for turkey captivity shifts through time, and (3) what the record of turkey penning informs us regarding the long-term human management of these birds and global perspectives on human-bird/human-animal management. Ancestral Pueblo peoples created an adaptive and flexible strategy for turkey penning, which successfully integrated these birds into ceremonial and socioeconomic processes for approximately 1600 years.
\end{abstract}

Keywords Turkey $\cdot$ Meleagris gallopavo $\cdot$ Pen $\cdot$ Captivity $\cdot$ Dung $\cdot$ Dropping

In the American Southwest and Mexican Northwest (SW/NW) ${ }^{1}$, the last several decades of archaeological research indicate that Ancestral Pueblo peoples engaged in a complex relationship with turkeys (Meleagris gallopavo spp.). Current genetic insights from ancient turkey mitochondrial DNA (mtDNA) studies confirm that in the pre-contact SW/NW, Pueblo peoples kept, raised and exploited "domesticated" turkeys with two genetically identified haplogroups (Kemp et al. 2017; Speller 2009; Speller et al. 2010). These turkeys were often fed domesticated maize (Zea mays),

\footnotetext{
${ }^{1}$ This paper focuses on archaeological sites in Arizona, Utah, Colorado, New Mexico, and a single site in northwestern Mexico (Paquimé). While Paquimé is distinct from the majority of archaeological sites discussed in the text, it is included here as an important example of human-turkey interaction within this broad geographic region.

Cyler Conrad

cylerc@lanl.gov; cylerc@unm.edu
}

Extended author information available on the last page of the article 
allowed to free-range and exploit non-maize plants and other resources, or a combination of both (Conrad et al. 2016; Jones et al. 2016; Kellner et al. 2010; Lipe et al. 2016; McCaffery et al. 2014, 2021; Rawlings and Driver 2010). Domestication and subsequent husbandry of turkeys likely occurred for a variety of purposes, but current data suggests that exploitation of eggs for food and paint creation (Beacham 2006; Beacham and Durand 2007; Conrad et al. 2016); feather gathering and collection for use in ceremonial activities and blanket production (Fewkes 1892; Lipe et al. 2020); use of bones for flutes, whistles, ornaments, and a variety of tools (e.g., Fewkes 1900; McKusick 1986); and subsistence (Badenhorst and Driver 2009; Hargrave 1965) all played important roles. Based on the altruistic relationship often identified between humans and turkeys through the presence of broken and healed turkey bones in Ancestral Pueblo habitation sites (Fothergill 2012, 2016; A. Morris 1933), the abundance and diversity of turkey/bird iconographic imagery in rock art and ceramics (e.g., Lange 1950; Schaafsma 1980), and the presence of intentional turkey burials (Lyle 2017a, 2017b), it is clear that these birds held a special role in past Native American society.

Given the role of ancient DNA in establishing that pre-contact peoples kept different types of turkeys that were treated similarly, and specifically husbanded turkeys (i.e., aHap1) for at least 1600 years (AD 1-1600; see Lipe et al. 2016; Speller et al. 2010), an aspect of this human-turkey interaction which remains unclear is how turkeys were kept, confined, and penned (or not), if this penning is consistent across time and space, and what variation in turkey penning indicates regarding human management strategies. For example, stable isotope data clearly reflects a human role in feeding or providing access to maize, but what is less clear is how Ancestral Pueblo peoples structured their habitation sites to control the breeding and feeding of turkeys. Evidence of formal turkey pens, reuse of abandoned rooms, and physical restraint of turkeys using tethering are all aspects of past turkey management vis-à-vis penning or confinement (see summary in Lipe et al. 2016), but a disparate state of understanding exists for what this evidence means and how it is identified.

Based on this record, here, I examine the evidence for turkey penning from across the Ancestral Pueblo world to contextualize why archaeological sites, through time, include localized concentrations of turkey dung, eggshells, and occasionally feathers, suggesting the presence of pens. In some cases, there are formalized and constructed pens, while in others, there is a lack of evidence for pens but presence of turkey evidence (e.g., isotopes, mtDNA, healed bone trauma) suggesting human management and/or confinement of birds. By providing a synthesis of the archaeological, historical, and ethnographic evidence for turkey penning/captivity in the SW/NW, and an examination of turkey penning through time, it allows for a contextualization of turkey penning and the underlying purpose and role of turkey pens and management within past Native American society.

\section{Organization, Scope, and Terminology}

This research is organized into three main sections: (1) a historical/ethnographic overview of turkeys, turkey pens, and turkey domestication based on DNA; (2) archaeological evidence for turkey pens (organized by time [earliest to latest] and 
region [northern/northeastern Arizona, to southern Utah, Colorado, New Mexico, and northwestern Mexico], using key historical examples - Turkey Pen and Pindi Puebloas relative baselines); and (3) a discussion of how this evidence relates to identifying turkey pens, temporal change in turkey penning, long-term human management of turkeys in the SW/NW, and inferences regarding human management of birds and other domesticates around the world. Throughout these sections, I use previously published historical and archaeological literature to form the basis of my interpretations and discussion. However, it is important to note that the sample of evidence presented in this research (> 40 Ancestral Places, i.e., archaeological sites) is not exhaustive. It likely captures the most prominent and well-documented sites with turkey pens in the SW/NW - and those that have formed the basis of several historical interpretations regarding human-turkey relationships - but it certainly does not represent every site.

Evidence for turkey pens that are not included in this research are likely found within cultural resource management reports and other documents prepared, published, and/or presented to Tribal, State, and Federal agencies or other private entities. These are typically documents that are more difficult to access and evaluate, but they are nonetheless significant for future studies as they almost undoubtedly contain additional insights into human-turkey relationships. For example, one site discussed below was excavated as part of a salvage project along New Mexico State Highway 32 in Catron County, New Mexico (Kayser 1972). That report describes the results of archaeological mitigations at several sites, and a close read clearly indicates the presence of a turkey pen, but only in a minor mention comprising two sentences. Additional examples of turkey pens must exist in the SW/NW and this review should therefore be considered as an evaluation of a large sample of known sites.

Given that the majority of information presented in this research derives from previously published accounts, I also interchangeably use both the metric and English systems of measurement as reported in original source material. Although this does not allow for standardization of metrics throughout the text, it does limit any introduced error by correcting all units presented to one standard form, especially since it is often unclear from source material how those units were measured and recorded.

In this research, I also use the term "Ancestral Pueblo" almost exclusively when referencing the peoples, places, and contexts which include these past turkey pens in the SW/NW (in certain areas I also use the terms "Native American" and "Indigenous"). While many of the archaeological sites discussed are ancestral, affiliated, and today located on Pueblo lands, I also recognize and acknowledge the cultural affiliation of many of these places to Athabaskan speaking peoples of the Navajo Nation and Apache Tribes, among other Tribal Nations.

Throughout this research, I also refer to, discuss, and examine human management of turkeys instead of human domestication or husbandry of these birds. Animal domestication is a complex process involving both human and animal behaviors and actions that aim to achieve certain characteristics within targeted populations over periods of time (Zeder 2006, 2012, 2015). The ultimate trajectory of domestication is, of course, a domesticated organism - but for what purpose or reason that organism "is" domesticated, and what "domesticated" means, varies. Here, I accept, and summarize below, that for turkeys in the Ancestral Pueblo SW/NW, past humans simultaneously managed turkeys within two genetically identified haplogroups. In most of the contexts with turkey pens, we lack clear evidence of the genetically constructed view 
of these turkey types, but for sites with genetic evidence, turkeys of either genetic ancestry are treated similarly (see Lipe et al. 2016 and below). For this reason, I follow Zeder's definition of animal management (2015: 3192):

the manipulation of the conditions of growth of an organism, or the environment that sustains it, in order to increase its relative abundance and predictability and to reduce the time and energy required to harvest it

This focus on management, instead of strictly the turkey domestication process or the process of turkey husbandry (i.e., breeding; see Marshall et al. 2015; Russell 2002), allows for greater flexibility in understanding the processes of human interaction with these birds. While it is impossible to untangle human management in turkey domestication and breeding process (Munro 1994; Thornton 2016; Thornton and Emery 2017), here, I accept that both wild and domesticated, husbanded turkeys co-existed and instead focus on investigating the management of turkeys through captivity and penning.

It is also important to define several terms that appear throughout this text. I use the terms turkey "droppings" and "dung" in various descriptions. While these equally relate to forms of turkey excrement, their differences are significant. When referring turkey "droppings," I accept and assume that these are typically desiccated, intact, pieces, or fragments of turkey feces (see Bailey 1956 for examples). This is often supported by descriptions of the excrement in source material. In contrast, turkey dung typically relates to compacted masses of partially decomposed turkey droppings and other materials in which individual pieces of feces may not be identifiable. Dung tends to appear in archaeological contexts as thick yellow mats of organic material.

Finally, throughout this research, and also discussed below, it is clear that turkey pens have a variety of forms and construction in Ancestral Pueblo contexts. This makes defining pens particularly challenging. Previous research defines turkey pens as "enclosures coated in layers of consolidated turkey droppings, and are often located in abandoned rooms," (Munro 1994: 58); however, I caution that this definition is accurate with several caveats. Defining a pen requires identifying deposits of turkey droppings or dung, but the form and structure of those contexts is variable and dependent on localized, site-specific conditions. (Re)Defining turkey pens is a component of the discussion to follow.

\section{Historical Perspectives on Turkeys, Penning, and Domestication}

Studies of turkeys in the SW/NW often rely on a series of proxy datasets to gauge how Ancestral peoples exploited these birds (Munro 1994, 2006, 2011). The presence or absence of turkey bones, their quantitative distribution, evidence of butchery (cut marks), burning, interment, bone taphonomy (including presence of medullary bone- a formation of bone which occurs in bird hens to function as a calcium reservoir), sexing, aging, genetics (based on ancient DNA), diet (based on stable isotopes), movement and origin (based on radio isotopes), and evidence gained through turkey products (i.e., feathers, eggs, gastroliths) or iconography-among others - all help provide inferences on pre-contact human-turkey interaction. Evidence for turkey 
pens is involved in this collection of data - and historically, prior to the involvement of osteometrics and ancient DNA (e.g., Badenhorst et al. 2012; Breitburg 1988; McKusick 1980, 1986; Speller 2009; Speller and Yang 2016; Speller et al. 2010), instances of perceived turkey pens resulted in broad conclusions regarding humanturkey relationships. Specifically, that turkeys were "kept" or "captive" in a "tame" or "domesticated" state. These insights helped create a framework for how archaeological studies identify turkey pens, enclosures, and structures assumed to function as locations of direct human management of these birds (e.g., Schorger 1966).

In Nordenskiöld's (1893) documentation of his trip and excavations in the Mesa Verde region of southwestern Colorado (Fig. 1), he aptly described these pen contexts (1893: 95):

Several circumstances lead us to the conclusion that the cliff-dwellers kept some bird, probably the turkey, in a domesticated state. Huge layers of excrement occur in the open space already mentioned on several occasions, which lies at the back of the cave in the more extensive cliff-dwellings. At Step House, where these deposits lay beside the ruin, their depth was 0.6-2.0 m., their breadth $13 \mathrm{~m}$., and their length $40 \mathrm{~m}$... The brothers Wetherill, who are experienced ranchers, consider these excrements, which are in a very good state of preservation, to be turkey droppings.

Nordenskiöld and the Wetherill's also identified turkey dung deposits, similar to this description, in Spruce Tree House (1893: 52-54; see also Fewkes 1909). At this latter ancestral village, at least one turkey pen - located in the northern portion of the cavewas almost entirely dark when inhabited by "tame turkeys" as the wall of the inner structure reached almost to the roof and blocked out natural light. Nordenskiöld postulated that, "it cannot have been a very pleasant abode for them" (1893: 52). ${ }^{2}$ This type of early description is significant since it helped establish, presumed, causal relationships between turkeys, specific archaeological deposits, contexts, and ultimately human management strategies. A synthesis of bird bones from archaeological sites in Arizona and Utah, published in the 1930s, helps support this interpretation. Working with turkey bones from several sites such as Turkey Cave- - which was named for the presence of turkey pens and abundant droppings (Breternitz 1969) - the assumption was simply that, "[a]rchaeological data, I believe, are sufficiently convincing to permit the statement that the turkey was under domestication," in this region (Hargrave 1939: 208).

When anthropological archaeological studies began to focus on turkeys in the early/ mid-twentieth century, these same assumptions bore through interpretation. For example, Reed (1951: 196) described that "[s]uch finds as enclosures containing droppings, which obviously were turkey pens, show that the San Juan Anasazi unquestionably

\footnotetext{
${ }^{2}$ Turkeys themselves ensured that archaeologists would not pleasantly experience excavating their pens. While excavating Poncho House in northeast Arizona, a "pernicious dust" of "pulverized turkey droppings" caused "dust to rise in choking clouds" that temporarily made several field crew members sick, including one who caught pneumonia and was left permanently disabled (Guernsey 1931: 55-56).
} 


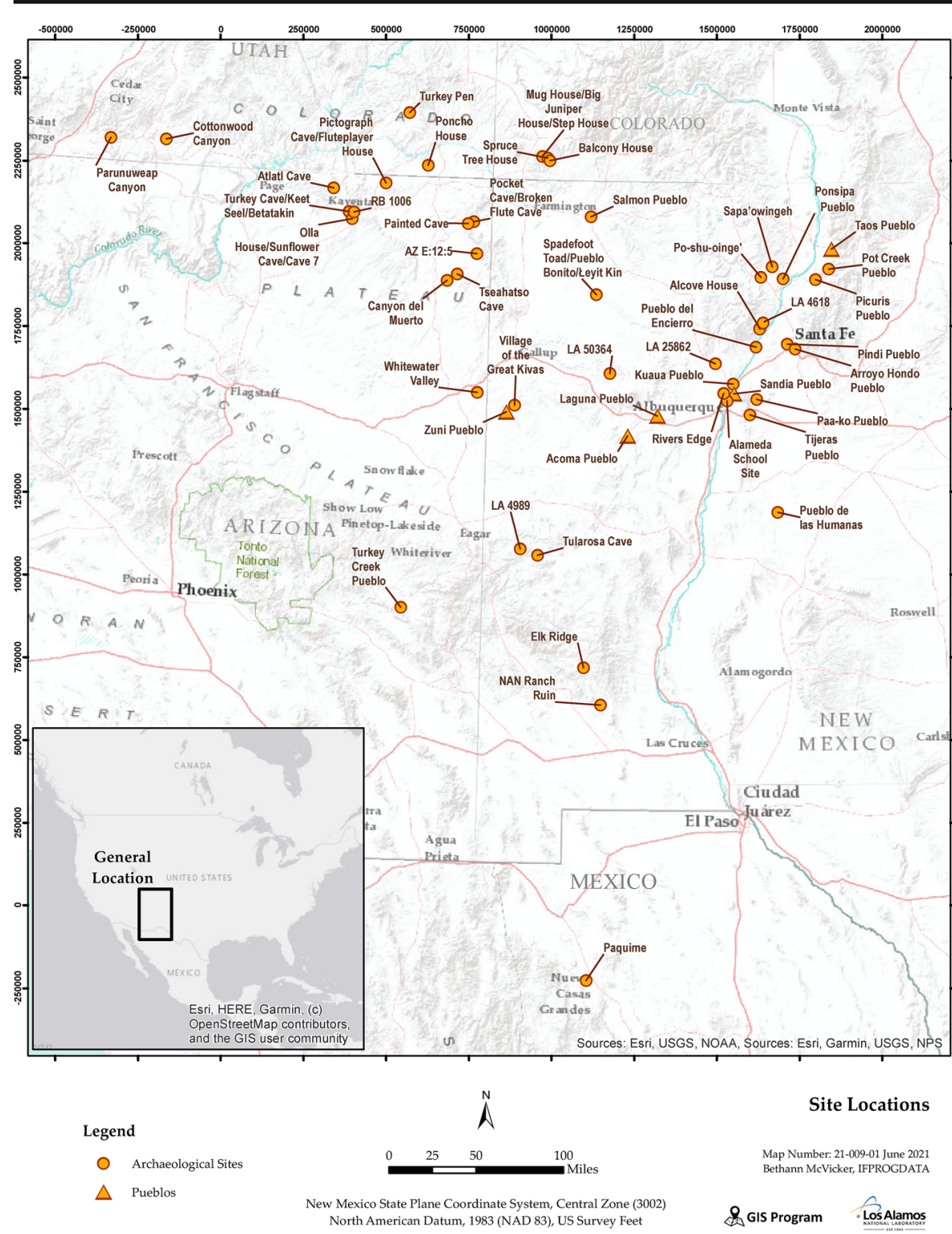

Fig. 1 The location of modern Pueblo Nations (triangles) and Ancestral Places (i.e., archaeological sites; circles) discussed in-text

kept turkeys as domestic fowl.” Another example comes from Schorger (1961:141), when discussing the desiccated Tularosa Cave turkey:

The literature is void of definite information on what the captive turkeys ate, and whether they were allowed to forage or were kept confined. It is known that practically every pueblo had its turkey pen and that in the cliff dwellings the pen was located in the rear of the cave...Several of the early Spanish accounts 
mention turkeys in pens, but none of which I am aware speaks of them as running loose. Most of the pueblos were so situated that I doubt if even a Pueblo would have indulged in the labor of getting the turkeys up and down daily.

Schorger's comment is particularly telling as it speaks to the inherent complexity of identifying and understanding past turkey penning and confinement strategies due to the ethnohistoric biases that are embedded in those identifications. In many cases, there are clear archaeological examples for turkey pens evident through dung deposits within physical structures, yet sites with large turkey assemblages often have no evidence for turkey pens, and ethnohistoric and ethnographic descriptions provide expectations for both turkey penning, and the "free-ranging" of turkeys with or without formal captivity.

Spanish records and later nineteenth/twentieth century ethnographic accounts from the SW/NW indicate that while Pueblo communities often kept turkeys and exploited them for feathers, eggs, and occasionally meat (Beidleman 1956; Cushing 1920: 357; Lange 1950; Reed 1951; Winship 1896), they were "penned"-or managed - similarly to introduced, domesticated sheep (Fig. 2). Functionally, this meant that turkeys were allowed to range during the day, but were kept corralled within villages, or near villages, at night (Fig. 3; Cushing 1979; 182-183; Mindeleff 1891: 214-215). During the 1581 Chamuscado-Rodriguez Expedition to the Rio Grande Pueblos, a journal record documented that " $[\mathrm{t}]$ here is not [a Native American] who does not have a corral for his turkeys, each of which holds a flock of one hundred birds" (Simmons 1979: 179). Gunn (1917: 26) also wrote that "[a]t Laguna and Acoma were formerly large droves of turkeys; they were herded something after the manner of sheep" (see also Gallegos Lamero 1927: 26; Hodge 1910: 321).

In 1583, during the Espejo Expedition, a note indicates that Pueblo people kept numerous turkey blankets, "because they raise cocks and hens in quantities" (Hammond and Rey 1966: 172). Pueblo stories, such as the "Turkey Girl" also support this interpretation, as they describe turkeys being moved and kept outside or nearby villages (Cushing 1901; Naranjo 2008). Parsons (1996) noted that several Pueblos kept turkeys, but there was variation present in whether these birds were eaten, or how they were specifically used. For example, at Taos Pueblo, captured, confined and raised wild turkeys occurred within the village (Schorger 1961). An associated record suggests that turkeys kept within village enclosures were only used for ceremonial purposes (i.e., feathers) and that Pueblo peoples only consumed "wild" (i.e., non-captive) turkeys (Hewett and Dutton 1945: 113). Historic records also note that Sandia Pueblo, Jemez Pueblo, Acoma Pueblo, and Laguna Pueblo kept turkeys, some of which were "domesticated" and were allowed to "run loose about villages" (Bandelier and Hewett 1973: 37, 82, 97, 104)-clearly Pueblo peoples confined turkeys to varying degrees in the post-contact era.

It would take until the 1980s before archaeologists created formal arguments regarding the domestication of turkeys. Based exclusively on turkey morphometrics/ osteometrics, one argument suggested that multiple groups of domesticated turkeys were introduced to the SW/NW from elsewhere (i.e., Mesoamerica/Eastern USA) and a second argument suggested that turkey domestication occurred within the SW/NW itself from progenitor wild Merriam's turkey populations (see Breitburg 1988; McKusick 1980, 1986; and summaries in Munro 2006, 2011). This debate existed until the application of ancient DNA and stable isotope analysis to Ancestral Pueblo turkey specimens and associated modern turkeys - but the answer was not exhaustively 


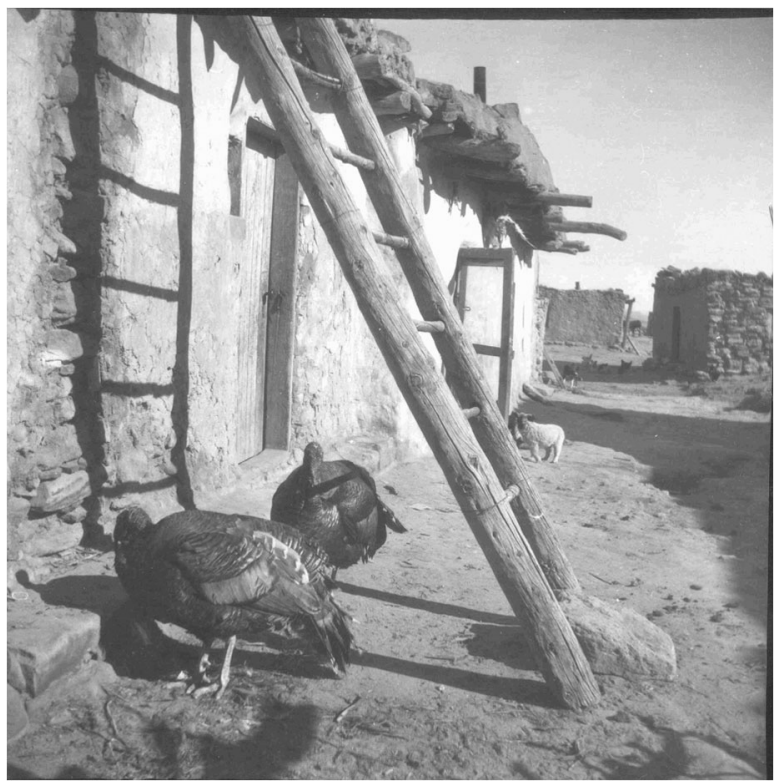

Fig. 2 Turkeys and a sheep at First Mesa, Hopi Pueblo Original photograph by Kate Cory, 1905-1912. Courtesy of the Museum of Northern Arizona (MS-208-75.929)

conclusive. Ancient DNA (mtDNA, only a measure the matrilineal line) confirmed that Ancestral Pueblo peoples interacted with and exploited turkeys within two haplotypes, aHap1 and aHap2 (or haplogroups, H1 and H2) in the SW/NW (Kemp et al. 2017; Speller 2009; Speller et al. 2010), but there are no physical size differences in the birds matching these types (i.e., not identifiable through morphometrics/osteometrics based on current data). One haplogroup, H1, represents a "domesticated" form of turkey that is most closely related to turkey populations that are today located in the eastern USA (or perhaps a heterogeneous pre-contact Merriam's turkey population), while the second haplogroup, H2, represents the local “wild” Merriam's turkey (M.g. merriami)

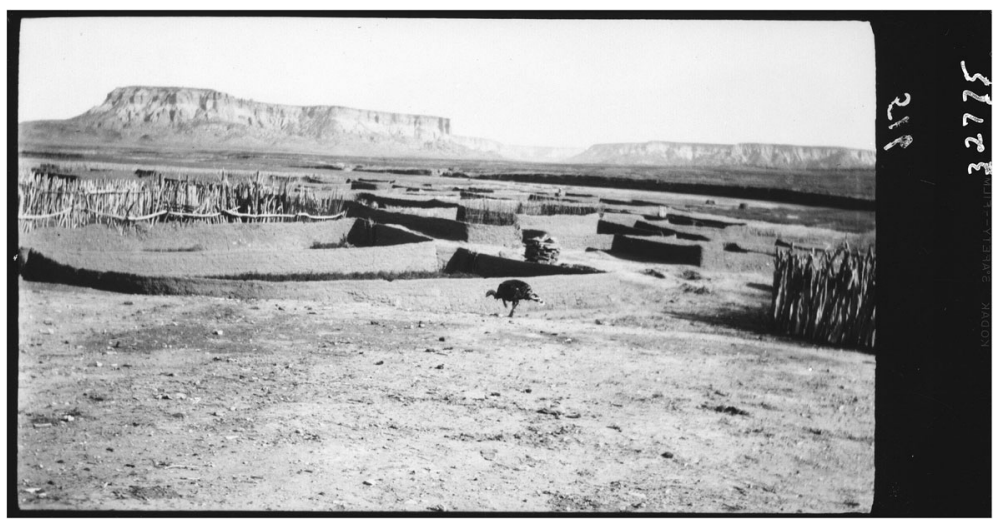

Fig. 3 A turkey within a walled-in garden at Zuñi Pueblo. Original photograph by George H. Pepper (ca. 1903). Photograph courtesy of the National Museum of the American Indian, Smithsonian Institution (N32775, NMAI.AC.001.034) 
and Gould's turkey (M.g. mexicana). However, birds with both of these haplogroups experienced similar treatment by Ancestral Pueblo people and were often provisioned with maize - they were "domesticated" turkeys. Humans clearly controlled the breeding of $\mathrm{H} 1$ turkey hens, based on low genetic diversity and introgression identified within turkeys of this haplogroup, but presence of $\mathrm{H} 2$ haplotypes within $\mathrm{H} 1$ turkeys indicates that there was low-level interaction and/or breeding of Merriam's turkeys with H1 turkey stocks for $\sim 1600$ years (Lipe et al. 2016: 109). As Lipe et al. (2016) discuss, this may have occurred through captive management of Merriam's turkeys, occasional breeding of captive $\mathrm{H} 2$ hens, or the presence of $\mathrm{H} 2$ haplotypes in the progenitor population of turkeys domesticated and kept by Ancestral Pueblo people in the SW/ NW. Unfortunately, H1 turkeys went extinct in physical form (their genetics survive in H2 Merriam's populations today), sometime during or after Spanish contact.

Given that historic records support Pueblo peoples continuing to exploit, pen and raise turkeys after this contact ${ }^{3}$ period, a facet of this relationship which is less clear is exactly how turkey pens were constructed and how these pens functioned within Pueblo society through time. There are detailed examples of sheep, horse and burro corrals at Zuñi Pueblo, and possible "corrals" at various ancestral villages in eastern Arizona/western New Mexico (Mindeleff 1891: 214-215), but no mention of turkey pens. ${ }^{4}$ Zuñi sheep corrals were constructed using wooden posts, occasionally with thin walls and masonry, in somewhat rectangular or rounded shapes within villages or along exterior village walls. Wooden corrals were constructed using posts/stakes and brush, tied together with horizontal poles and rawhide strips and braced with additional rock/post supports (Fig. 4). Occasionally, nooks within rock outcrops were used as pens, but at villages, constructed pens often, "form a nearly continuous belt around the pueblo" (Mindeleff 1891: 214). While these structures are specific to the herding and management of sheep, horses, and burros, there are also "miniature corrals" present that were constructed as cages for eagles. These cages were built against the side of pueblo homes (Fig. 5). Again, these accounts do not describe turkey pens or enclosures.

This gap in understanding is significant because the generalized documentation of turkeys in the post-contact era strongly suggests a form of small-scale pastoralism where Pueblo peoples allowed turkeys to range outside of villages - a potentially consequential conclusion for modeling pre-contact human-turkey interaction. And, while certain archaeological contexts support this interpretation at sites where known pens are not present (Jones et al. 2016; Young 1980), other contexts with clear evidence for turkey pens (Conrad et al. 2016; Lang and Harris 1984) do not. Therefore, an examination of the archaeological record is necessary to clarify the structure and diversity of turkey penning throughout the Ancestral Pueblo-era.

\footnotetext{
${ }^{3}$ Given the loss of $\mathrm{H} 1$ turkeys at contact, historic and ethnographic accounts of "domesticated" turkeys may be misleading — as they could represent remnant Ancestral Pueblo H1 turkeys, tamed wild Merriam's turkeys, or introduced Anglo-American domesticated turkeys which are descendant from ancient Mesoamerican stocks (see Manin et al. 2018; Speller et al. 2010).

${ }^{4}$ This may be due to the preference of sheep/goat over turkeys in the post-contact era (see Tarcan 2005; Tarcan and Driver 2010).
} 


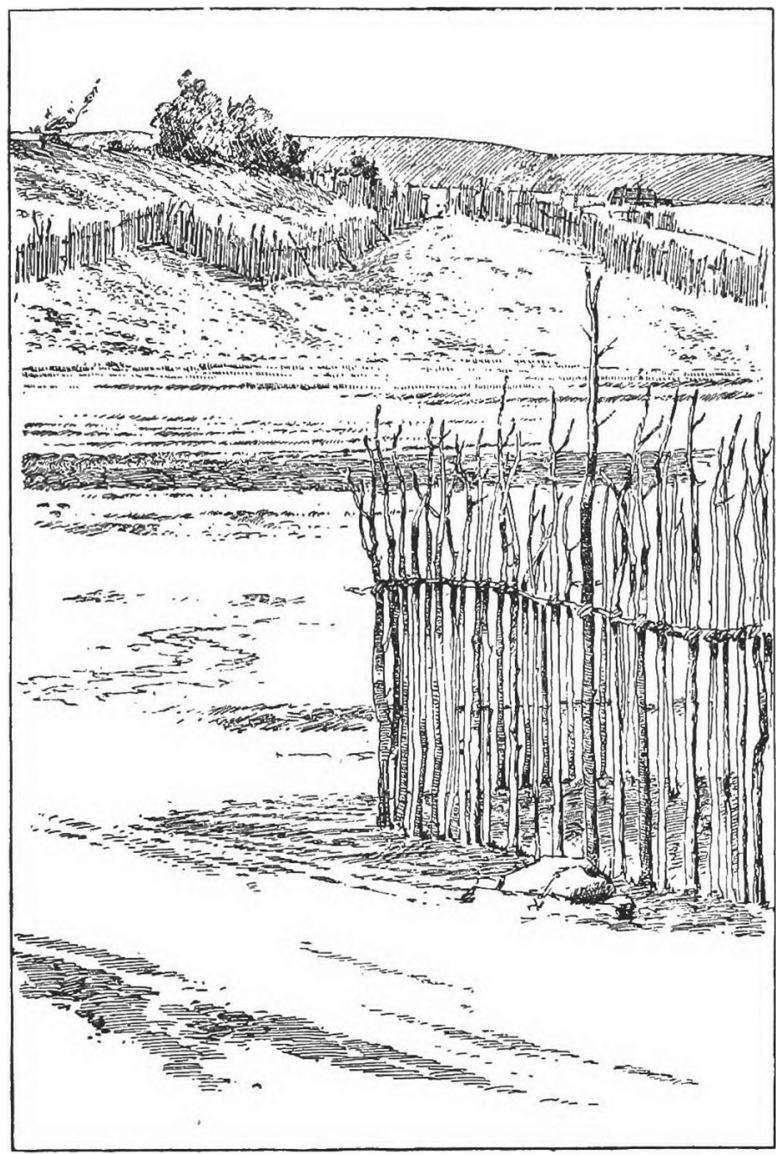

Fig. 4 An ethnohistoric drawing of an animal corral/pen at Zuñi Pueblo. The wooden post wall in the foreground represents an animal pen enclosure. Original drawing from Mindeleff (1891: Figure 109)

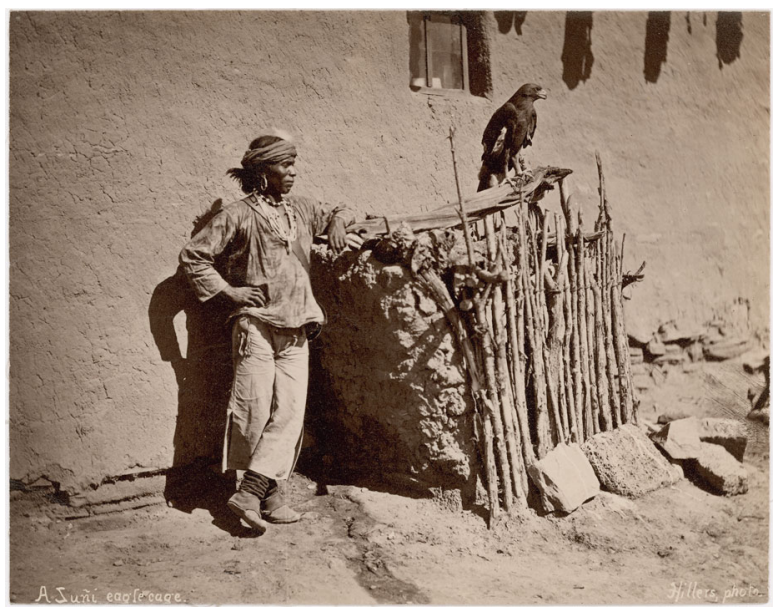

Fig. 5 An eagle cage at Zuñi Pueblo. It is unclear whether or not the eagle in the photograph is tethered (see Figs. 9a, b). Original photograph by John K. Hillers (ca. 1870s-1880s?). Photograph courtesy of the National Museum of the American Indian, Smithsonian Institution (P01966, NN35028) 


\section{Archaeological Evidence for Turkey Penning and Confinement}

\section{Shelters, Pit Houses, and Tethering}

From approximately AD 1-900, during the Basketmaker II-Pueblo I periods in the SW/ NW (see Reed 2000 chronological summary), evidence for turkey penning and captivity occurs in the form of simple tethering, confinement within caves and rockshelters, and use (or reuse) of pit houses/structures, masonry rooms, and simple fenced/adobe areas. The quintessentially named Turkey Pen site in Grand Gulch, southeastern Utah (Lipe 1979; Lipe et al. 2016: 98-101), provides an example. At Turkey Pen, which is a large rockshelter site, there is evidence for a possible (unexcavated) brush and mud structure that has been informally referred to as a turkey enclosure (Fig. 6; see Bedell 2000). This enclosure likely dates to AD 1060-1270, but in excavated midden deposits, far from the enclosure (see Matson 2018) and dating to AD 1-200, there are abundant, distributed turkey droppings and feathers present. The genetic signature of a sample of these turkey droppings indicates that approximately $75 \%$ are from the domesticated Ancestral Pueblo turkey H1 haplogroup lineage with $25 \%$ identified as the H2 haplogroup lineage (Speller et al. 2010 and see above), and macrobotanial and pollen analyses from these samples confirm that both aHap1 and aHap2 turkeys consumed a diet heavy in maize (Nott 2010; see also Aasen 1984). Turkey bones are notably rare, as are eggshell fragments. There are also no "caked" deposits of turkey droppings in the shelter. The presence of a nearby water source, and thus probable ancestral location for crop growth, suggested to Lipe and colleagues (among others; Powers 1984) that the most parsimonious explanation for the turkey evidence from the Turkey Pen site is that it was not the location of a formal enclosure for confinement of turkeys (Lipe et al. 2016). Instead, these birds were likely drawn to this rockshelter through the presence of human activities (and food) and were ultimately exploited for their feathers (e.g., Lipe et al. 2020).

Although the Turkey Pen site itself does not represent a location where turkeys were clearly confined, it does help highlight what type of evidence might support this interpretation: physical structures with aggregated deposits of turkey droppings or dung. Several additional shelter/cave sites post-dating Turkey Pen support this interpretation.

In the Prayer Rock District of northeastern Arizona, excavations in Pocket Cave, east of Pit House 3 revealed a turkey pen, including evidence for turkey droppings and vegetation (E. Morris 1980: 18, 47). The structure itself was only partially excavated along the western wall where a row of $40 \mathrm{~cm}$ tall upright slabs in a circular shape, measuring $6 \mathrm{~m}$ in diameter, defined the extent of the space. Excavations suggested that the roof timbers were removed after use of this structure as a pen and prior to a fire event within the cave. At its greatest, this turkey dung deposit was approximately $95 \mathrm{~cm}$ thick. Pocket Cave has a single tree-ring date of AD 438. At Pit House 4 in Pocket Cave, the fill included numerous turkey feathers (presumably from turkeys kept in Pit House 3), but lacked evidence of droppings.

In contrast, at the nearby site of Broken Flute Cave in oval-shaped Pit House 9, there was clear evidence that the room burned and was later reused as a possible turkey pen (E. Morris 1980: 35). The charred layer, buried under a 20-50-cm-thick layer of vegetation, included infrequent artifacts and, "[f]rom top to bottom, turkey droppings 


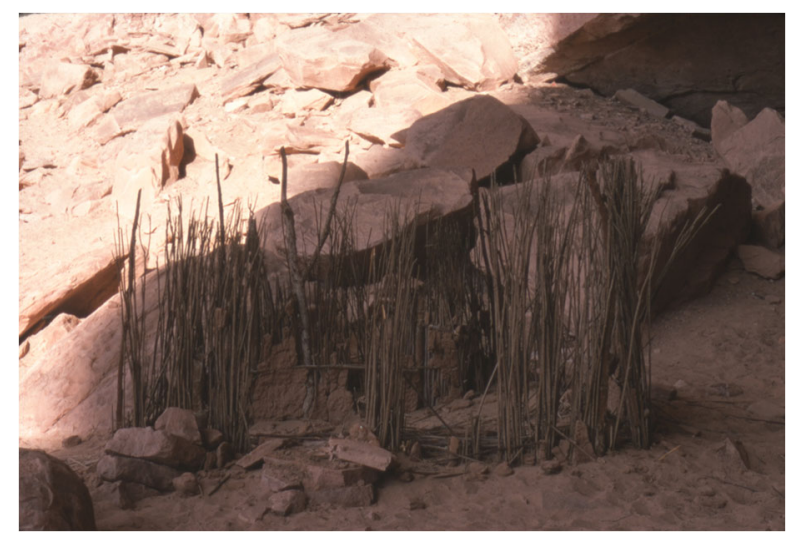

Fig. 6 A possible turkey pen at the Turkey Pen site in southeastern Utah. Note the wooden posts, likely originally encased in mud (along the back wall). Photograph courtesy of Bill Lipe, ca. 1974

were plentiful" (Figs. 7 and 8). Yet unlike Pocket Cave, turkeys were presumably penned in this structure without evidence of a roof, which suggests that very young, or maimed, turkeys were kept here. The same fire event that burned Pit House 9 also likely destroyed nearby Pit House 6 where, in a subfloor cache, excavations recovered a hide bag filled with turkey beards but no evidence for droppings (1980: 28, 91-92). Other turkey evidence from Broken Flute Cave and elsewhere included a basket approximately two-thirds filled with turkey feathers, cordage wrapped with split turkey feathers, and possible turkey bone awls and/or whistles (1980: 32, 80-87, 103). Pit Houses 6 and 9 in Broken Flute Cave have a series of cutting and non-cutting tree-ring dates ranging from AD 602-627 with a single early date of AD 515 (non-cutting) identified from Pit House 9.

Several other cave sites in northern Arizona exhibit similar evidence, including at Painted Cave (Haury 1945: 26), where excavations identified "a turkey pen, including a nest with three eggs" in a small masonry structure at the eastern edge of the site. In Tseahatso Cave, turkey pens occurred behind and within the "living quarters," and excavations revealed a buried, feathered turkey carcass with a splinted, broken leg intentionally set by Ancestral Pueblo peoples (exact dating is unclear for the pens; A. Morris 1933: 196-197; Quirolo 1987). McKusick (1986: 5) references a personal communication to Lee Abel that indicates 300 "natural mummies" of turkeys also occurred at Tseahatso. At Atlatl Cave a cist (Feature 18) found within stratified sediments contained a 10 -cm sediments of turkey feces, feathers, vegetal material, and maize (Geib et al. 1999). A direct radiocarbon determination on a maize cob provided an uncalibrated date of $1500 \pm 60$ years before present (Beta-68382; 432-650 calibrated AD using OxCal v4.4 and the IntCal20 calibration curve). ${ }^{5}$ Preliminary

\footnotetext{
${ }^{5}$ Radiocarbon dating of a second kernel from this deposit provided an age of $1025 \pm 37$ uncalibrated years before present, suggesting that the turkey pen is more recent than originally determined or that maize kernels from more recent activities became mixed into the older deposit. Two additional un-published direct dates on turkey droppings tend to support the latter interpretation and suggest a long-term use of this cave for turkey penning (Personal communication, Philip Geib, 2021).
} 


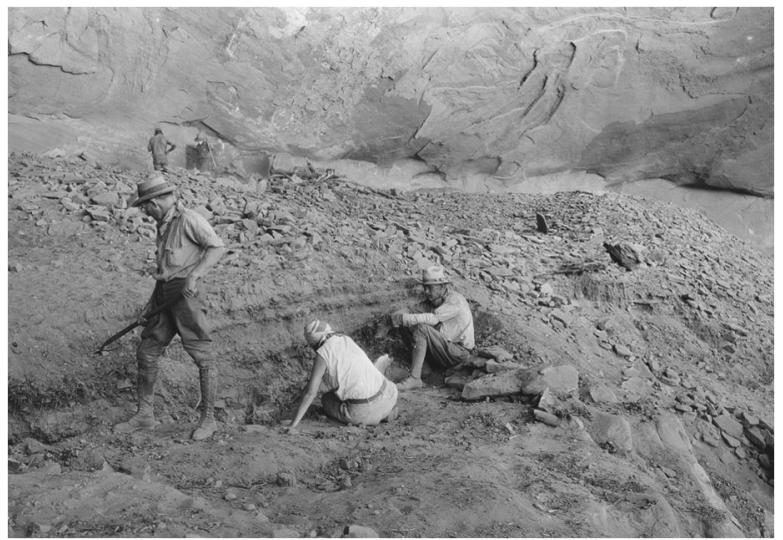

Fig. 7 Broken Flute Cave, Pit House 9, early during the excavation. Note the blackened burn layer at knee level (for the individual standing on the far left). Excavators recovered turkey droppings above this layer. Courtesy of the Arizona State Museum, University of Arizona, Earl Morris, photographer (\#5803)

results from Atlatl Cave show a majority of turkeys belonging to the dominant domestic haplotype seen elsewhere in the SW/NW at this site (Newbold et al. 2011).

A series of turkey pen deposits were also identified during the 1914-1915 archaeological excavations in the Kayenta District/Monument Valley of northeastern Arizona. Ruin 4 (also called Pictograph $\mathrm{Cave}^{6}$ ) revealed the presence of a large quantity of turkey droppings and feathers along the cave wall and within several masonry rooms (Kidder and Guernsey 1919: 36-37). Thirty feet east of the Pictograph Cave kiva (east of the masonry rooms) was a structure approximately $18 \mathrm{in}$. in diameter, and $1 \mathrm{ft}$ deep, that had a three-sided "wattled fence" and was interpreted by Clayton Wetherill as a "nest for setting turkey hens" (1919: 39). Excavations did not recover eggshells, but there were turkey droppings and feathers in and around the enclosure. At a related site, Ruin 5 (Fluteplayer House) in Room 5, sediments located against the back cave wall were filled with turkey droppings $2 \mathrm{ft}$ deep in some locations (1919: 45). South of this area and Kayenta, excavations identified turkey droppings within the back cave floor deposits and cists in Sunflower Cave (1919: 96; Guernsey and Kidder 1921: 6), and at the nearby Ruin 7 (or Olla House), a cist located between a kiva and adjacent boulder was filled with turkey droppings (1919: 51-52). The spaces between formal masonry structures at Olla House also exhibited evidence for turkey pens or "nests." Construction of these nests occurred by digging small hollows, $1 \mathrm{ft}$ in diameter and eight in deep, faced with adobe, and they contained abundant turkey droppings and feathers. Between these two sites, in Cave 7, turkey droppings and feathers also occurred in tandem (Guernsey and Kidder 1921: 32). A deposit at site RB 1006 southwest of Kayenta also provided evidence of a "mass of clay containing eggshell fragments" assumed to be turkey and found at the intersection of two walls, suggesting to the original investigators that this was a possible ceremonial deposit (Beals et al. 1945)—or more likely, a location for keeping turkeys.

Basketmaker pit houses located on an open-air ridge in the nearby Lukachukai Valley of northeastern Arizona also suggest an intentional creation of turkey pens

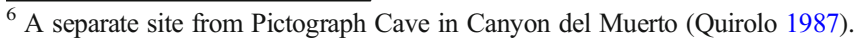




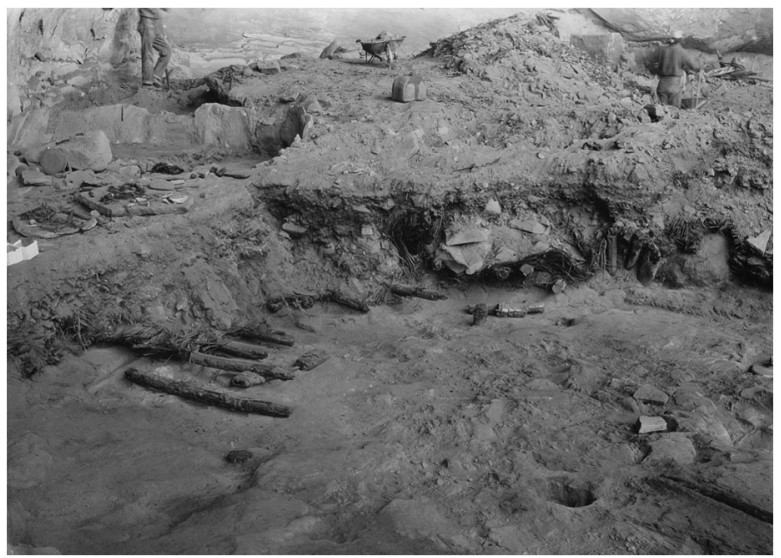

Fig. 8 Broken Flute Cave, Pit House 9, during the final phases of excavation. Note the blackened burn layer and the thick turkey droppings/vegetal deposits above this layer. Courtesy of the Arizona State Museum, University of Arizona, Earl Morris, photographer (\#5806)

during this era. For example, at AZ E:12:5 in House Cluster 65, dating to the early AD $600 \mathrm{~s}$, two rows of posts were constructed to the east of the structures to, presumably, enclose an area that likely functioned as an animal pen (Altschul and Huber 2000: 150). The structure to the east of these pens included a cache of turkey bones which provided support for the probable keeping of turkeys in this enclosed area at the site.

While the early Ancestral Pueblo-era in the SW/NW includes several examples of turkey penning, it is important to note that this period also saw the emergence of turkey tethering (Fig. 9a, b). Excavations recovered a desiccated turkey with a yucca cord wrapped around its neck in a small Basketmaker cave in Canyon del Muerto, northeastern Arizona (Schorger 1970). Additional examples of tethering are also known from southeastern Utah (Lipe et al. 2016: 106), and a single turkey tethering event is likely present at Arroyo Hondo Pueblo, post-dating this era (see below). Evidence for this form of human penning, or captivity, is significant as it highlights direct and individual human-turkey interaction.

Turkey dung and eggshell deposits are also known from sites (i.e., ZNP-2 and 21) in Zion National Park, southern Utah (Schroeder 1955) and elsewhere in New Mexico. An important site with turkey evidence, but no clear pen features, is Tularosa Cave. Here, excavations recovered a desiccated adult turkey, desiccated chicks, turkey eggs, and "great quantities of the droppings" (Hough 1914: 5-6; Schorger 1961), but no record of a physical structure representing a pen, dating to the Pine Lawn Phase (150 BC-AD 500), or at least 1000 years ago (Martin et al. 1952; but see also Koons and Nash 2015). In contrast, at LA 25862, located northwest of Albuquerque, New Mexico, on an ancient Jemez River terrace, lenses of abundant turkey eggshells in Pit House 2 (Feature 10) dating to the late $\mathrm{AD} 700 \mathrm{~s}-800$ s suggest use of this space as a pen, but only after it was abandoned (Cordero and Dicks 2010) ${ }^{7}$. These Basketmaker and early

\footnotetext{
${ }^{7}$ Several contemporaneous, and earlier, pit house sites south/southeast of this location near Corrales, New Mexico, provided evidence of turkey skeletons, gastroliths and turkey bone trauma. No pens are present, but turkeys were clearly kept and exploited during this early period in the Middle Rio Grande (see Frisbie 1967; Schmader 1994; personal communication, Matthew Schamder, 2021).
} 

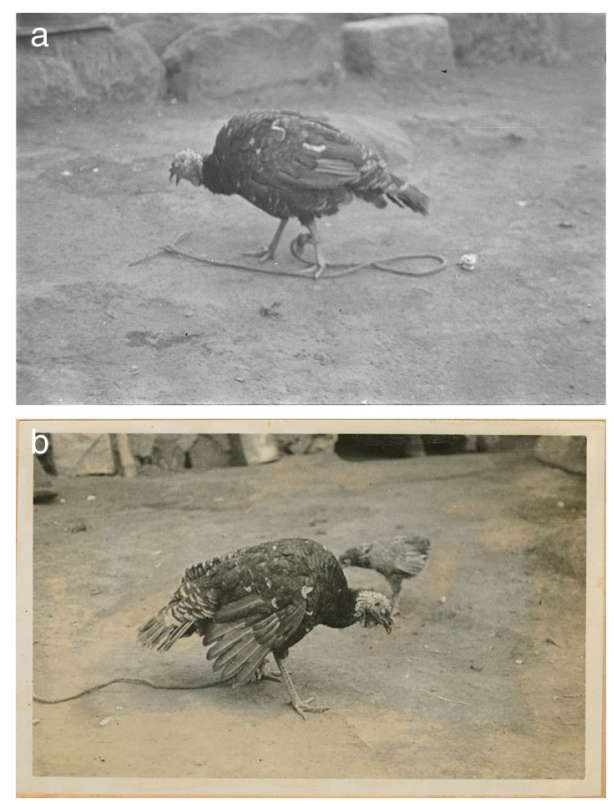

Fig. 9 a An example of a tethered turkey from Atitlan, Guatemala (ca. 1920s/1930s) titled, "Death of a turkey." Courtesy of the Peabody Museum of Archaeology and Ethnology, Harvard University (58-34-20/ 69649). b A second view/example of the tethered turkey (with an un-tethered chicken in the background) from Atitlan, Guatemala (ca. 1926-1932) titled, "Turkey," photographed by Dr. Samuel Kirkland Lothrop. Courtesy of the Peabody Museum of Archaeology and Ethnology, Harvard University (2004.1.393.347)

Pueblo-era records clearly reflect the widespread keeping of turkeys in pens throughout the SW/NW.

\section{Pueblo Plazas, Rooms, and Enclosed Spaces}

Immediately post-dating this period, from approximately AD 900-1600 (Pueblo IIIV), evidence for turkey penning and confinement occurs in the form of physical pens constructed in pueblo plazas, rooms, or locations created through the anthropogenic enclosure of spaces (i.e., within rockshelters/caves). Pindi Pueblo, located southwest of Santa Fe, New Mexico, directly adjacent to the village of Agua Fria along the Santa Fe River, exhibits this type of turkey penning. Dating to the AD 1200s-1300s and excavated in the 1930s, there was such an overwhelming abundance of turkeys and evidence for turkey management present at the site that the excavators termed the village "Pindi Pueblo" using a rough Anglicization of the Tewa word for turkey (Stubbs and Stallings Jr. 1953; see also Henderson 1914). At Pindi Pueblo, there were four formalized turkey pens located in the southeast corner of the village plaza (Fig. 10) which were constructed out of vertical wooden posts and twigs (Stubbs and Stallings Jr. 1953: 12, 47). Using the exterior plaza roomblock walls for support, these pens were relatively large-Pen 8 (the far southeast corner pen) likely measures approximately 10 by $10 \mathrm{ft}$ (based on the published site map), or over $100 \mathrm{ft}^{2}$ in area. Excavations did not note evidence of roofs over these plaza pens. 


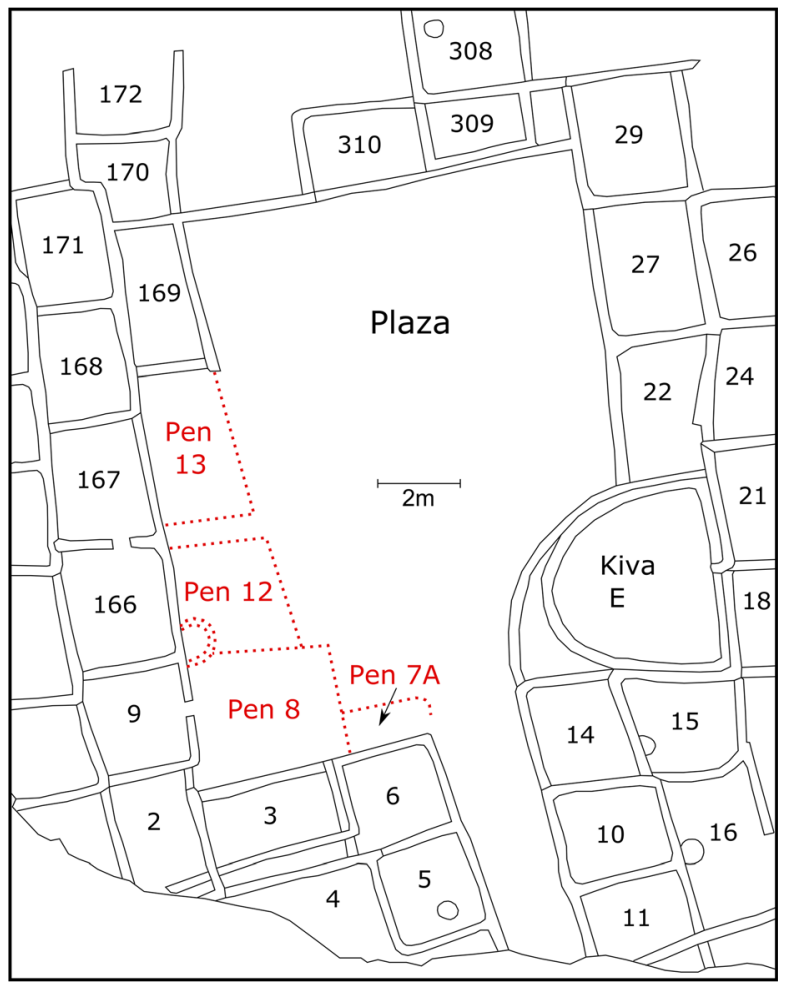

Fig. 10 Digitized map of the Pindi Pueblo plaza and pens from Stubbs and Stallings Jr. (1953)

Within each of these physically constructed pen enclosures, excavations revealed, "a soft, yellowish material made up of disintegrated turkey manure," along with numerous turkey bones, eggshell, and at least in one case (in Pen 12) a fragmented culinary jar that likely served as a turkey watering bowl. In the northern portion of Pindi's plaza, the original construction and use of Kiva $\mathrm{E}$ and the northeastern rooms also functioned as turkey pens given the identification of yellowish fill under the floors. One feature, a small 3-ft diameter stone and adobe "coop," between Pens 8 and 12 in the plaza, likely functioned as a pen for an individual bird - although the specific type of bird is unknown (see comparison in Fig. 5). ${ }^{8}$ Pindi Pueblo yielded abundant turkey bones, turkey bone whistles, and other tools, along with iconographic imagery of turkeys on ceramics (1953: 48-60; 126-136). The evidence for turkeys at this site proved significant for guiding how archaeologists identify and interpret turkey confinement strategies throughout the SW/NW.

Turkey Cave (AD 1200s; Breternitz 1969; Guernsey 1931: 57), located in northeastern Arizona and named for the "enormous" amounts of turkey droppings present in the site, also functioned as turkey pen based on the presence of two surface structures (Anderson 1969). This site is just north of Keet Seel, which is a large 160-room-pueblo village along the canyon wall dating to AD 950-1300. In refuse/midden deposits at

\footnotetext{
${ }^{8}$ Stubbs and Stallings (1953: 47) argue this may have been an eagle pen, based on ethnographic descriptions from Zuñi Pueblo (Mindeleff 1891: 215).
} 
Keet Seel, deposits of turkey droppings and a "very hard-packed yellow-brown organic layer" suggest the presence of pens (Anderson 1971). Analysis of five turkeys dating to AD 1250-1300 indicated the presence of Ancestral Pueblo domesticated birds (aHap1) at this village site (Speller et al. 2010). Betatakin, a 135-room-pueblo south of Keet Seel also has evidence of turkey pens (see Di Peso 1974a).

An additional site in northeastern Arizona provided evidence of a turkey pen based on a "thick layer of turkey droppings" on the floor of Pit House 13a, including broken eggshells and an individual turkey skeleton (Roberts 1939: 118). A separate structure included a child burial with a turkey on one side, a dog on the other, and associated jars and bowls placed at the heads of all three individuals (Roberts 1940: 135-136). A turkey burial next to an adult human was also identified in earlier dating contexts outside of Kayenta (see Beals et al. 1945).

While less clear, several additional sites likely included turkey pens while occupied during this era in southern Utah. Although exact site names and descriptions are unknown, Pueblo III caves in Cottonwood Canyon and Parunuweap Canyon include evidence for, "turkey roosts, droppings, feathers and even bits of egg shell [sic]" (Thomas 1952).

Sites in the Mesa Verde region of southwestern Colorado also exhibit evidence for turkey pens. At Big Juniper House ( AD 1080-1150), abundant turkey bones, bone tools, and turkey gastroliths occur throughout the site, but a maul-shaped object (or reused maul) with surface spalling suggested the presence of a "turkey tether-enabling a turkey to walk about, but heavy enough to keep it from flying or running away" (Swannack 1969). At Balcony House, Schorger (1961: 142) noted collecting turkey droppings in the shallow cave $300 \mathrm{ft}$ from the main site. Formal excavations at Balcony House included the presence of abundant "animal droppings" in the refuse area behind the masonry structures and just below the north plaza (Fiero 1998). As previously described, Step House and Spruce Tree House (Fewkes 1909) also have large accumulations of turkey excrement. At Mug House (AD 1000s-1100s), turkey gastroliths, bone elements, burials, bone tools, feathers, small amounts of eggshell, and turkey tethering stones all supported the presence and exploitation of turkeys at this site, including the penning of birds in Room 46/1 along the back shelter wall (Rohn 1971). Excavations indicated that this rectangular room was the largest at the site at $105 \mathrm{ft}^{2}$ and contained turkey droppings, maize (and other vegetation), and turkey gastroliths - and was the only location at the site with "matted dung." Desiccated droppings occurred throughout most of the site deposits, but this matted cluster in Room 46/1 suggests the presence of a pen.

Chaco Canyon and the Four Corners region of northwestern New Mexico also include several sites with evidence for turkey pens. Eggshells, turkey bones, maize eating turkeys (based on stable isotopes), local turkeys (based on strontium isotopes), domesticated turkeys based on ancient DNA, gastroliths, feather artifacts, droppings, and iconographic images all support the keeping or penning of turkeys at Chacoan Great Houses, specifically Pueblo Bonito (AD 900-1100s; see summary in Conrad 2020). A narrative of captive birds at Pueblo Bonito suggested that, "[e]agles and redtailed hawks moped in wickered cages; [and] imprisoned turkeys begged crumbs and sunflower seeds" (Judd 1925: 241) — a description likely inspired by the presence of turkey droppings and intact botanicals in Room 92 (a possible pen) at the pueblo. Smaller Chacoan villages also include evidence for pens. An example occurs at the 
Spadefoot Toad site (AD 900-1140) in Room 9 where small masonry cists suggested the presence of turkey pens based on numerous eggshell fragments clustered in fill deposits after the cists were abandoned from their original use (Fig. 11; Windes 1993: Figures 4.12 and 4.16; see also Windes 1977). Eggshells also occur in relative abundance at several other Chacoan sites, including Łeyit Kin (AD 1000-1100; Dutton 1938: 75; see also Akins 1985).

At a related and associated Chacoan site, Salmon Pueblo (AD 1090-1280s), located outside of Farmington, New Mexico, excavations recovered mixed evidence for turkey penning. Although abundant turkey skeletal remains (including burials), eggshells, broken and healed bones, and turkey feather blankets occur at this village, there are only three possible turkey pens present (Beacham 2006; Beacham and Durand 2007; Durand and Durand 2006, 2008; Durand and Ortega 2018; Reed 2006). These pens are located near the central kiva (Room 62B) and in the far southeastern roomblock (Rooms 127E and 128A-B) and provided possible evidence of turkey captivity. In Room 62B, which was a small division of the larger Room 62, wooden posts occurred within the subdivided wall suggested a turkey pen in this space (Reed 2006: 149). In Room 127E, which is the eastern portion of Room 127, excavations revealed the presence of a small $1.5 \mathrm{~m}$ by $1 \mathrm{~m}$ "storeroom" possibly used as a pen-presumably because of its shape and size (Reed 2006: 221). Finally, in Room 128A-B, a long, $11 \mathrm{~m}$ by $2.2 \mathrm{~m}$ room, turkey bones, eggshells, and the presence of a "pit-pen" of unknown size suggested turkeys were kept within this space (Reed 2006: 223-225).

At LA 50364, near Ambrosia Lake in northeastern New Mexico, turkey eggshell, young poults, and adult individuals all with a variety of evidence for healed bone fractures and disease recovered in a kiva and mealing room contexts suggested the possible presence of penning (Bertram 1990). Other possible pens in New Mexico occur in the Middle Rio Grande at the Alameda School Site where excavations recovered a cache of ochre painted eggs (Cordero 2013), or Pueblo del Encierro (AD 1275-1550) where excavations recovered a turkey burial, cut and burnt turkey bones, and possible turkey dung (Guiles and Ford 1978: Table F1). At the Village of the Great

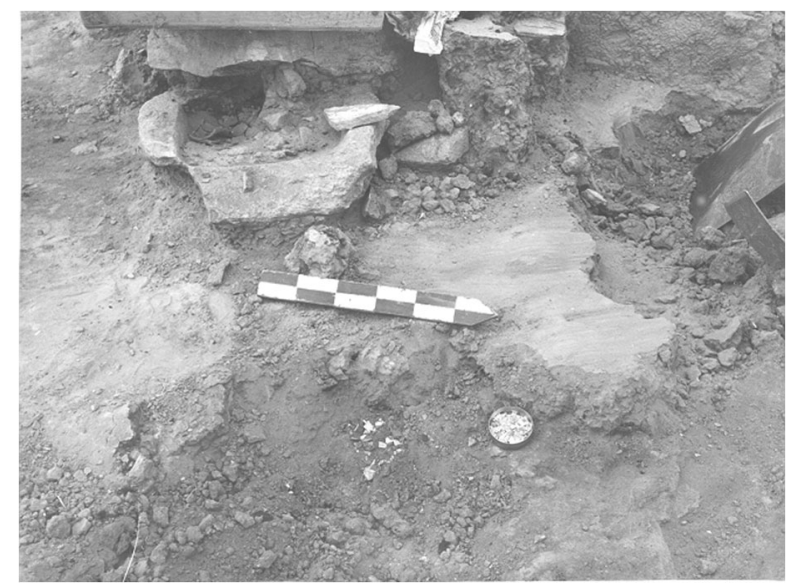

Fig. 11 Eggshell fragments in the fill above the floor in Room 9 at the Spadefoot Toad Site, looking west (September 8, 1975). See Windes (1993) Figures 4.12 and 4.16 for overview of bins. Courtesy of Chaco Culture National Historical Park (0002/018.004/01/0010616) 
Kivas in Zuñi Pueblo (likely dating to between AD 1100-1200), eastern New Mexico, a detached (from the village) long, narrow, and rectangular shaped corridor with low masonry walls indicated the possible presence of a turkey pen-but it was noted that "the place itself gave no indication that it had functioned in that capacity," aside from an individual turkey skeleton recovered from this context (Roberts 1932: 47; see additional sites mentioned by Mindeleff 1891). Curiously, at Alcove House (also known as Ceremonial Cave), located on the Pajarito Plateau in northern New Mexico, while original excavation reports do not note any presence of turkey pens (Hewett 1909a, 1909b), a 1930s National Park Service report on this site details the presence of possible turkey pens (with droppings) against the back cave wall and in reused kiva fill deposits (Meem 1939).

A related and nearby ancestral village southeast of Santa Fe in northern New Mexico, Arroyo Hondo Pueblo (AD 1300-1425), also contained evidence for 18 turkey pens, among other turkey items and objects (Lang and Harris 1984: 102). Two types of turkey pens are present at Arroyo Hondo: (1) abandoned rooms directly adjacent to plazas which were converted into turkey pens and (2) formal pens constructed in plazas, adjacent to roomblock walls, with wooden posts (Fig. 12) - possibly interlaced with other vegetal material or mud. In four cases, turkey pens (in Plaza C) were constructed beneath an overhang, providing a protected roof. In other plaza pens, horizontal poles constructed into the roomblock wall functioned as elevated roosts for turkeys within pens. The size of Arroyo Hondo's pens varied, but of the eight formal plaza enclosures excavated, they averaged $10 \mathrm{~m}^{2}$ in area.

Within these turkey enclosures, evidence for depressed nesting areas, eggshells (including a clutch of eggs in a Plaza K pen; see Figure 3 in Conrad et al. 2016), fragmented ceramic vessels that likely functioned as watering bowls and "soft, lightweight, yellowish material, presumably turkey dung, mixed with wind-deposited sand, eggshell fragments, vegetal remains, and small quantities of cultural material, mainly ceramics" occurred in deposits 7-23 cm thick (Lang and Harris 1984: 103). A dense, concentrated accumulation of turkey dung in one location within Plaza $\mathrm{C}$ suggested

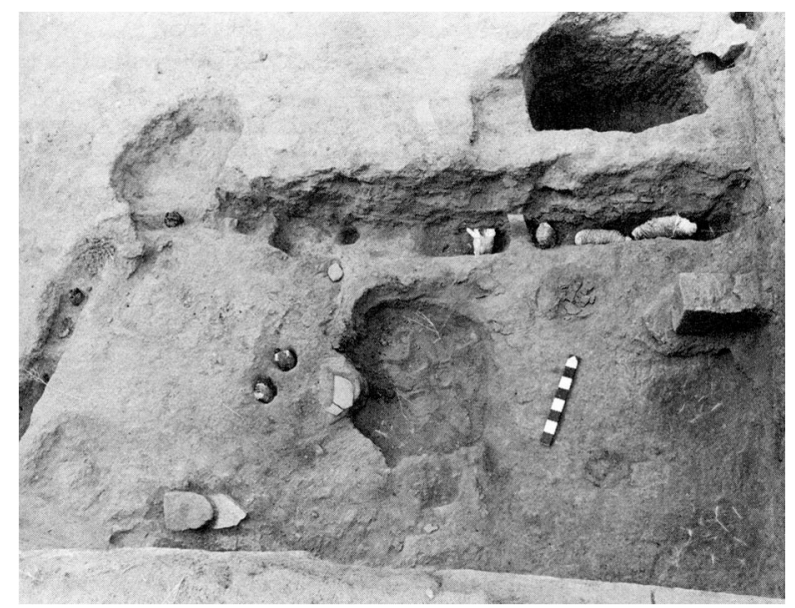

Fig. 12 A formal turkey pen in Plaza G at Arroyo Hondo Pueblo. Original photograph by Richard Lang(?), see Lang and Harris (1984: Figure 14). Courtesy of the School for Advanced Research 
possible tethering of an individual turkey (see Fig. 9a, b for examples). Broken and healed turkey bones, burnt and cut marked elements, and turkey iconography on ceramics are also present at this village site.

Elsewhere in northern New Mexico, several other Ancestral Pueblo villages occupied during this era support evidence for turkey penning. At one of the largest known pre-contact villages in the northern SW/NW, Sapa'owingeh (or Sapawe) - with approximately 2000 rooms and seven plazas dating between the late $\sim$ AD 1300s1600 s - excavations revealed an overwhelming abundance and focus on turkeys and penning (Steele 2018; Windes and McKenna 2018). At Sapawe, similar to Pindi Pueblo and Arroyo Hondo Pueblo, wooden posts defined turkey pens along the margins of plazas (against roomblock walls) and in lower-level rooms next to plazas. Enclosed Plaza A exhibited the largest number (Personal communication, Peter McKenna, 2021). Although a formal site report does not exist, photographs from the excavation highlight the presence of yellow turkey dung deposits in room pens adjacent to plazas (Fig. 13). Excavations identified over two dozens of these pens at the site. Pueblo peoples also buried at least 38 turkeys throughout Sapawe and numerous turkey skeletal elements, worked bone, healed turkey bone breaks, and the presence of turkey iconography on ceramics indicate that the village may have functioned as a "turkey farm" for the trade of feathers (Emslie 1981: 324; see also Steele 2018).

At Po-shu-oinge' Pueblo, southwest of Sapawe and dating to the AD 1300s-1400s, excavations in 1919 revealed numerous turkey bones, worked bone whistles, turkey iconography on ceramics, and "wild" turkey eggs. Within $1 \mathrm{~m}$ deep deposits in the southwestern corner of Plaza 2 there is an ephemeral presence of a turkey pen:

When first uncovered one of the eggs was almost entire. Only a small part of one end was gone and the yolk could be plainly seen inside of the shell. In a short time the yolk fell to dust and the shell also crumbled somewhat. In many places in the excavation we found bits of pottery with portions of eggshells still adhering to them, and often where there were no shell remains there was a decided yellow stain from the yolk (emphasis added; Jeançon 1923: 68-69).

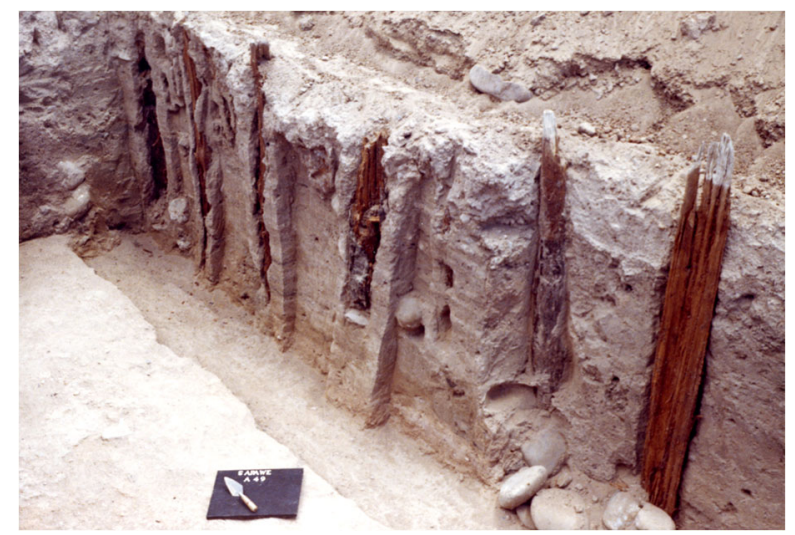

Fig. 13 Room 49 at Sapawe Pueblo showing the presence of yellow turkey dung deposits (see lower profile wall). Courtesy of the Maxwell Museum of Anthropology, University of New Mexico (2010.35.1494) 
Plaza B (Rooms 79-2, 79-3) and Plaza A at Ponsipa Pueblo, north of Po-shu-oinge,' functioned as turkey pens based on the identification of turkey skeletons, including juvenile birds, broken ceramic vessels, and between "several walls...thick layers of turkey dung" (Bugé 1981; Dombrosky 2015). Plaza A also included a 20-50-cm-thick layer of turkey dung within an enclosed space defined by a "crude stone wall." In Room 7 at Kuaua Pueblo north of Albuquerque, excavations identified articulated turkey skeletons, disarticulated bones, turkey bone tools, fragmented ceramics assumed to function as turkey watering bowls, a bin feature with a partially intact single egg, and numerous eggshell fragments which were interpreted as a turkey "nest" (Kelly 1934). Room 10 at Kuaua also had a small adobe bin present, suggesting the presence of a second turkey nest.

In southern New Mexico, turkey pens also occur, relatively uniformly, from several sites. At LA 4989 (the Gann Site; AD 1150-1350), excavations in Room 1 identified three adobe wall compartments with small doorways that were blocked, leaving small niches (Kayser 1972: 12). In these compartments, unidentified bird bones and a "large amount of turkey dung," suggest the presence of turkey pens. Turkey burials, bones, and eggshells from Elk Ridge (AD 1000-1130) indicated clear exploitation of turkeys, and in Room 110 - which was a cobble-lined storage room with a basalt entry plug and no formal floor, measuring $55 \mathrm{~cm}$ by $1.1 \mathrm{~m}$ - excavations recovered a nearly complete turkey skeleton (Fig. 14; Roth 2018). This context strongly indicates the presence of a turkey pen given the turkey burial within a confined, enclosed space (Causey et al. 2018; personal communication, Barbara Roth, 2021). A very similar turkey pen feature exists at NAN Ranch Ruin (AD 1100) in Room 25/75 where a small walled bin (27 cm by $34 \mathrm{~cm}$ ) is suggestive of turkey keeping (Fig. 15; Shafer 2003: 65; personal communication, Harry Shafer, 2021). Turkey burials and bird effigies also occur at NAN Ranch Ruin.

Finally, in northwestern Mexico at the site of Paquimé (Casas Grandes), two plazas contained several hundred buried turkey skeletons, including eggshells, in 43 distinct adobe, rectangular pens averaging $1.18 \mathrm{~m}$ by $70 \mathrm{~cm}$ in size (Breitburg 1993; Di Peso 1974a). Paquimé Phase ( AD 1300s-1400s) Plaza 5-8 contained seven pens, while Plaza 3-13 contained 36 (Fig. 16).

Twenty of the pens in Plaza 3-13 were contiguous against the village wall (Di Peso 1974b: 268; 1974c). At least 255 turkey burials occur at Paquimé, including 149 headless turkey burials. Given numerous worked turkey elements and feather artifacts, it is likely that turkeys were kept and penned at this village primarily for feathers and ceremony.

\section{Discussion}

\section{Identifying Turkey Pens}

Based on this review of the variation present in the SW/NW through both time and space, confirming turkey pens in the archaeological record typically resides on the presence or absence of turkey excrement. Whether examining Basketmaker-era cave sites, or Pueblo-era large-scale villages, the context of turkey penning fluctuates, but while these contexts are diverse, they almost always include some form of turkey dung 


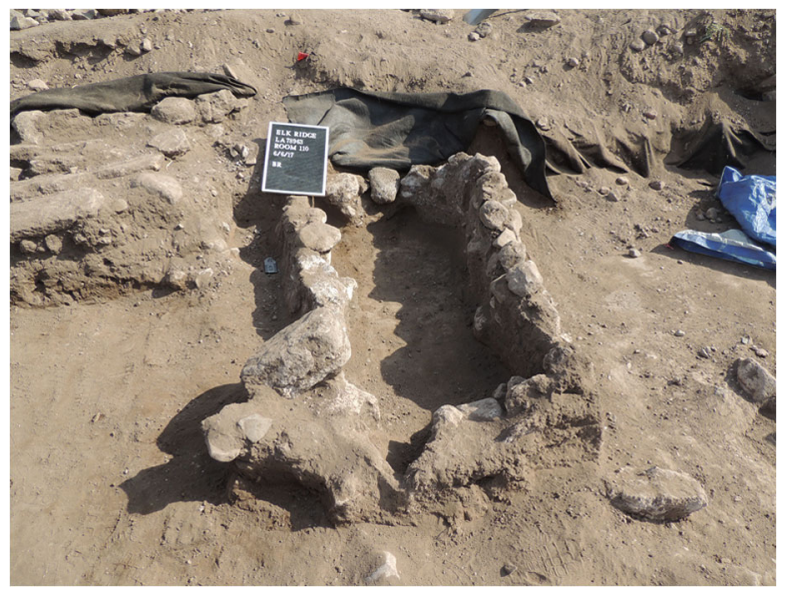

Fig. 14 The Room 110 cobble-lined storage room with a basalt entry plug from Elk Ridge. Photograph courtesy of Barbara Roth

or droppings. Constructed spaces, reused spaces, eggshells, watering bowls, feathers, and bones all could indicate the presence of a turkey pen, but without desiccated turkey droppings, or dense turkey dung aggregations, the evidence is marginal. For example, at Broken Flute Cave (E. Morris 1980) abandoned pit houses exhibit reuse as turkey pens, based on the presence of dense accumulations of turkey droppings. In another case, at Pindi Pueblo (Stubbs and Stallings 1953), turkey pens were intentionally created using physical wooden posts in plazas and elsewhere, and those structures

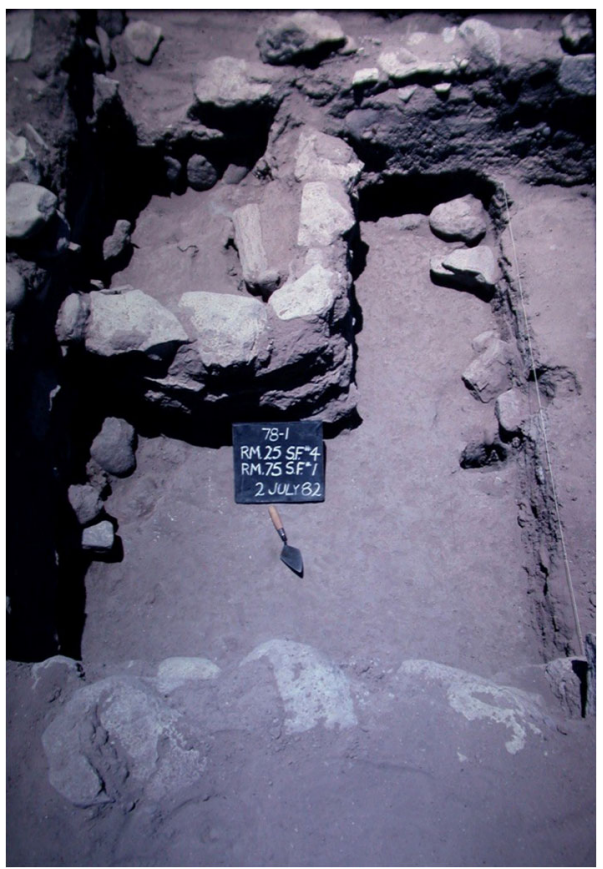

Fig. 15 The walled bin in Room 25/75 at NAN Ranch Ruin. Photograph courtesy of Harry Shafer 


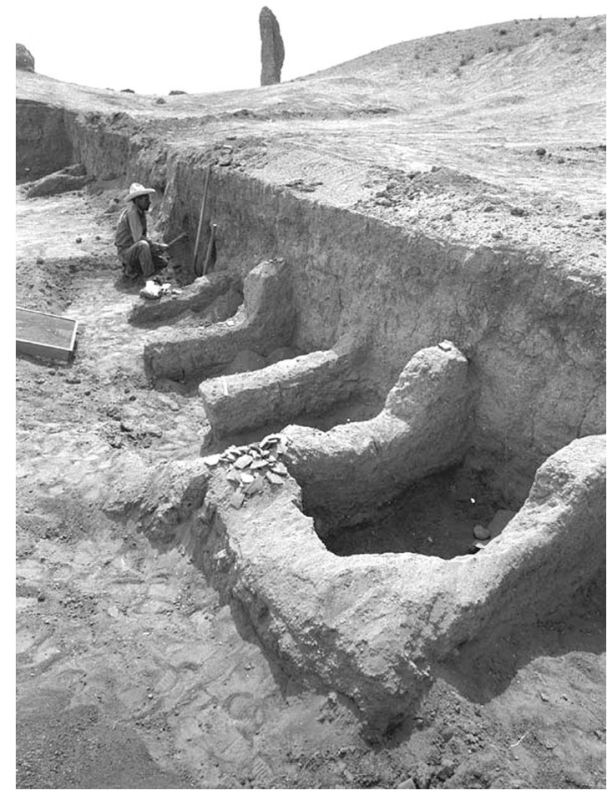

Fig. 16 Excavated turkey pens at Paquimé (Casas Grandes) in Plaza 3-13. Photograph courtesy of the Amerind Foundation, Inc.

include dense accumulations of turkey dung, including eggshells, bones, and other turkey artifacts. The key identifying characteristic at both sites is the localized accumulation of turkey excrement within these sites that help inform the location and definition of pens, regardless of associated materials within pens, the physical form of the enclosed space, or the type (dung versus droppings) and quantity of excrement.

One of the clearest examples of the variation and complexity present with identifying turkey pens in the archaeological record comes from the Turkey Pen site. As previously noted, ancient DNA and botanical analyses indicate the presence of Ancestral Pueblo domesticated turkeys eating domesticated maize at this site-both of which strongly suggest turkey captivity - but there is not a clear turkey pen present in the shelter itself (Lipe et al. 2016). A small wooden/mud enclosure (Fig. 6) could indicate a small turkey pen, perhaps for an individual bird, but there are no localized, aggregated deposits of turkey droppings or dung - only scattered desiccated droppings found throughout the shelter. Richard Wetherill described the shelter midden material as "[a]lso too filthy as it was composed almost entirely of desiccated turkey droppings [sic]" (see Lipe et al. 2016: 99). This pen also dates a millennium after evidence for turkeys consuming maize in this space. Turkey Pen thus likely does not represent a site with a defined turkey pen, but instead a location where turkeys aggregated through anthropogenic processes or otherwise. If the turkey droppings accumulated in only one portion of the site, that interpretation might change. For example, at Pictograph Cave in northeastern Arizona, a similarly built three-sided "wattled fence" structure likely functioned as a turkey pen based on the presence of droppings (this site also included aggregated turkey droppings within masonry rooms and along the cave wall; Kidder and Guernsey 1919). 
Another example of where droppings would help confirm the presence of a turkey pen occurs at the open-air wooden post structure created east of House Cluster 65 at AZ E:12:5 in northeastern Arizona (Altschul and Huber 2000: 150). Here, the presence of a turkey pen was inferred through the spatial characteristics of the wooden post structure - a location where animals could be kept and enclosed near habitation spaces. A cache of turkey bones east of this feature also supported the possibility of a pen. However, no clear turkey dung or droppings were identified within this site or context (a similar situation is found at the Village of the Great Kivas [Roberts 1932]). Were droppings present, this space would exemplify a turkey pen. Several sites throughout the SW/NW with this type of palisade or stockade construction often involve speculation towards whether they functioned as pens (Wilcox and Haas 1994) — but the lack of clear evidence, specifically dung and droppings, makes a final turkey pen conclusion difficult to confirm.

However, it is important to remember that the presence of other turkey materials, including eggshells, may also identify a pen in certain contexts. These contexts typically involve localized aggregation of materials but are more difficult to discern since eggshells may occur in archaeological sites for a variety of purposes - including capture/collection of non-managed, or "wild," turkey eggs for various purposes. Caches of turkey eggs occasionally occur in pens (e.g., at Arroyo Hondo Pueblo), but egg caches, or fragmented eggshells, also appear in many contexts that suggest a ceremonial, ritual, accidental, or other socioeconomic placement not within formal pen settings (e.g., at the Alameda School Site, or at Homol'ovi III [Senior and Pierce 1989]; see discussion in Conrad et al. 2016). For example, fragmented eggshells recovered throughout Room 28 at Pueblo Bonito do not indicate that this room itself functioned as a turkey pen during its early use (AD late 800s-900s), but rather a location of where eggshells were exploited from penned turkeys likely kept in Room 92, a nearby room with evidence of turkey droppings. Room 28 may have functioned as a turkey pen during its latest use in the AD 1100s (Crown 2020). Accumulations of eggshells within specific, confined spaces at the Spadefoot Toad site strongly suggest the presence of pens, even while there is a lack of droppings (Windes 1993). A similar situation is present at Salmon Pueblo where turkey pens were likely present, but not confirmed, and there is extensive evidence for turkey eggshells (see Durand and Durand 2006; Reed 2006). These contexts with eggshells, but a lack of turkey excrement, may suggest locations where turkey pens were cleaned by Ancestral Pueblo peoples, and dung moved (or used, perhaps as fertilizer) elsewhere (see discussions in Kohler 2012: 259; Manin et al. 2018: 9; Pinkley 1965: 72). It is difficult to hypothesize, however, why dung and droppings may be moved or cleaned but not eggshells from these contexts. The ephemeral or decomposed nature of turkey dung/droppings, and thus challenge of preservation and identification, may be influencing this record.

Archaeological examples of turkey pens help highlight that turkey excrement provides the clearest route for identification of spaces where turkeys were enclosed, kept, and presumably captive. The variation present in this record is nonetheless significant as it speaks to the adaptive flexibility that Ancestral Pueblo people practiced in their relationship with these birds - a pattern present when examining this record through time. 


\section{Temporal Variation in Turkey Penning}

While turkey-based research indicates that the role of these birds shifted through time from a bird exploited for feathers to a bird exploited primarily for food (Akins 1985; Badenhorst and Driver 2009; Lipe et al. 2020; Muir and Driver 2002), there are not clear corresponding diachronic changes in turkey pens (Table 1). Site type change occurs - from small-scale Basketmaker settlements ( AD 1-900; often within cave and rockshelter settings) to larger Pueblo villages or village aggregates ( AD 9001600; often in open-air settings) - but the adaptive characteristics of turkey penning remains unchanged through time. Captive management of turkeys by Ancestral Pueblo peoples took a variety of forms, and this diversity is present at the earliest, and latest, turkey penning NW. Clearly defined/NW. Clearly defined pens through time tend to have physical characteristics that restrict turkey mobility, and the presence of droppings, dung, or eggshell, but there is a flexibility and resiliency to the non-patterned nature of this evidence.

Several sites help explain this trend. At Pocket Cave, dating to the AD 400s, the intentional construction of Pit House 3 occurred to function as a turkey pen (E. Morris 1980). This space was large (6 $\mathrm{m}$ in diameter), defined (constructed with upright stone slabs) and full of turkey droppings. It likely represents a created space for turkeys. At Broken Flute Cave, dating to the AD 600s, Pit House 9 was originally constructed as a human habitation space, but after it was abandoned and burned it was reused as a turkey pen. Again, this space was large, $6.4 \mathrm{~m}$ in greatest length, and defined (as a formal subsurface pit house) which was full of turkey droppings. At Pictograph Cave, a possible wooden and mud structure may have functioned as an individual turkey pen (Kidder and Guernsey 1919). Although undated, the presence of desiccated turkeys with rope around their necks also indicates a form of tethering within a variety of possible spaces - likely caves - during these early periods (e.g., Lipe et al. 2016; Schorger 1970; see Fig. 9a, b for similar examples). Thus, during the first several centuries $\mathrm{AD}$, there are multiple forms of turkey pens or captivity occurring, including intentionally created spaces, reused spaces, and forms of individual bird management.

A millennium later, at sites such as Arroyo Hondo Pueblo and Pindi Pueblo, the same variation present in turkey penning occurs throughout larger village sites (Lang and Harris 1984; Stubbs and Stallings 1953). Both of these villages include evidence for created turkey pens within plazas and rooms, reused spaces (i.e., rooms/kivas) as pens, and individual-level bird captivity through tethering and caging - for example, with the accumulation of dung at Arroyo Hondo Pueblo suggesting tethering of an individual bird, and at Pindi Pueblo with a small, individual bird pen between two large plaza pens. And, while the type of turkey excrement present within these two village sites differs from earlier periods (e.g., aggregated mats of dung versus desiccated droppings), the size of turkey pen spaces is generally consistent in its variable form. Ancestral Pueblo peoples exploited both small and large areas in rooms, plazas, pit houses/features, and elsewhere to keep captive turkeys. Spaces also exhibit evidence for roofed and unroofed pens, suggested complexity in the third dimension of restricting turkey flight. Later dating sites also include evidence for individual-level penning of turkeys, for example in the small structure at Turkey Pen (Lipe et al. 2016), or with the turkey tethers at Big Juniper House and Mug House (Rohn 1971; Swannack 


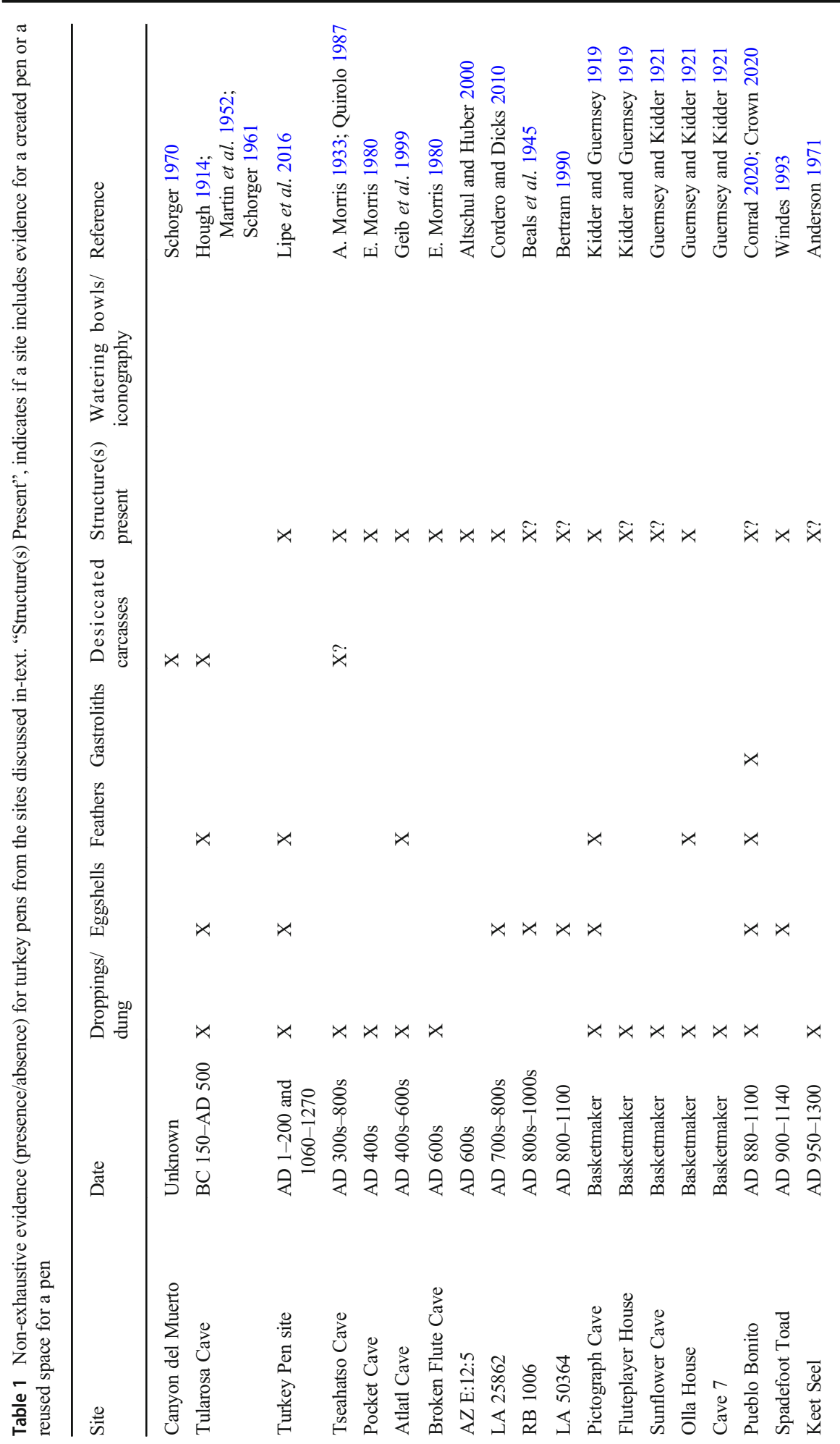




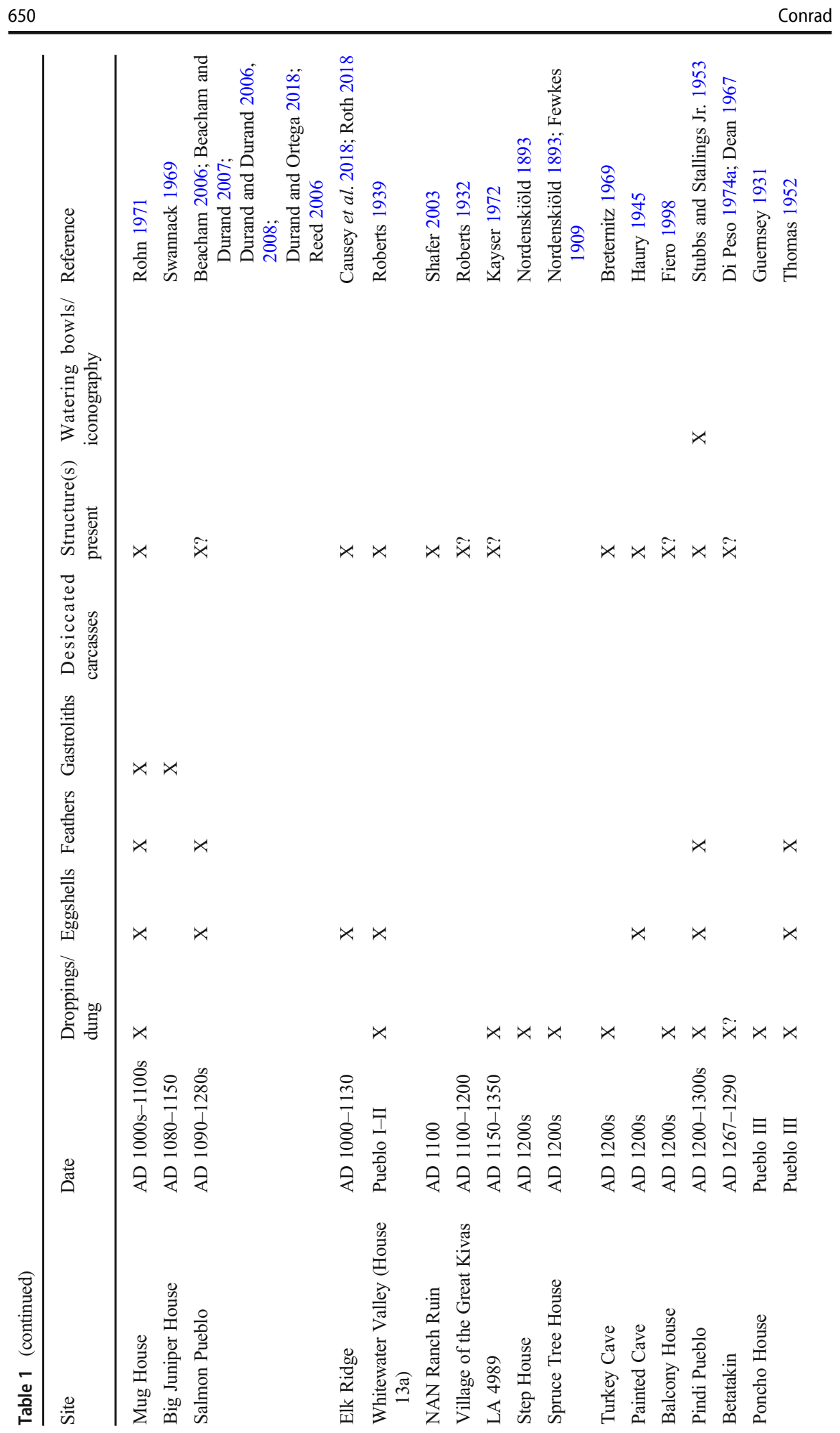

Springer 


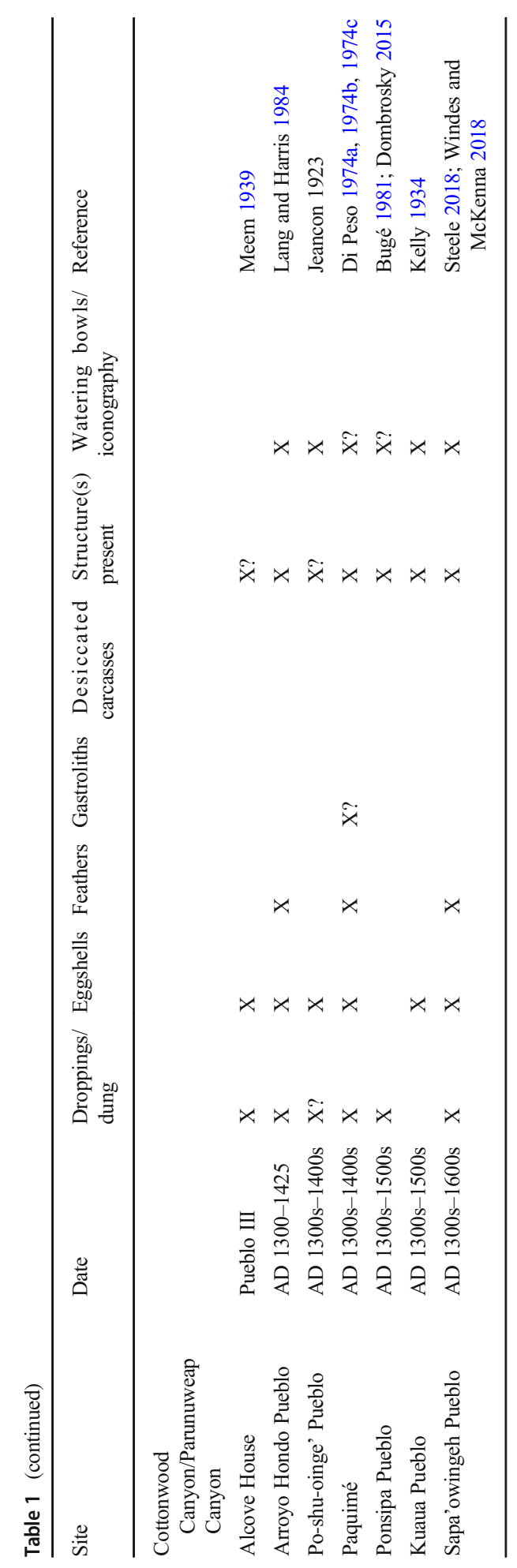


1969). The latter two sites also include evidence for larger-sized pens that would have held multiple birds captive and enclosed.

Consistent levels of variation present in turkey pens through time-created versus reused, large versus small, individual versus multiple - are not a result of archaeological bias limiting our understanding of the record. Instead, it represents a crucial element of Ancestral Pueblo human-turkey relationships in the SW/NW. Adaptive flexibility in this relationship allowed Pueblo peoples to remain resilient in their dependence on turkeys for a variety of purposes for over 1600 years, including during the post-contact era.

\section{Ancestral Pueblo Management of Turkeys and Pens}

Post-contact descriptions of turkeys within Pueblo communities often describe the pastoral nature of this relationship. Birds are allowed to range and forage during the day and are brought into or nearby villages at night. This record, in association with conflicting documentation regarding the use of turkeys (i.e., whether they were consumed), influenced a long period of archaeological thought regarding ancestral human relationships with these birds. Small abundances of turkeys in Basketmaker-era sites, little evidence for cut marks and burning (or other evidence for consumption), but extensive indication for the use of feathers and intentional burials paired with a "historic" record suggesting a primarily non-food function resulted in a now standard interpretation - turkeys were originally kept for feathers, not for consumption (e.g., see Lipe et al. 2020). Only later in the pre-contact era, once this evidence reverses, does turkey use supposedly shift to a primarily food function - turkeys were kept for food beginning in the Pueblo-era in the pre-contact SW/NW. While this research does not attempt to alter this narrative, it does stress the significance of a missing element, turkey penning, and how this record is more broadly understood when conceptualizing this human management strategy. By examining the diverse, functional characteristics of turkey pens throughout the SW/NW, and their apparent lack of change through timeor better - consistent levels of variation, we must contextualize and shift our understanding of Ancestral Pueblo turkey management. Here, examining where turkeys are penned is as equally important as examining where they are not.

Consider several sites. At AD 1-200 in Turkey Pen, there are aHap1 and aHap2 turkeys consuming a maize diet in a shelter without clear evidence for pens in excavated deposits (Lipe et al. 2016). Over 1100 years later, domesticated turkeys at Tijeras Pueblo are consuming both maize and non-maize "natural" diets (i.e., a $\mathrm{C}_{3}$ diet in carbon isotope space; Jones et al. 2016) in a large village setting also without known evidence for pens. Although these contexts are dichotomous in both time and space, the Ancestral Pueblo management of these turkeys through a lack of penning is nearly identical. In both locations, turkeys accessed anthropogenically derived maize, and Ancestral Pueblo peoples allowed the birds to remain non-penned in their environment. Likewise, at a related site, Pot Creek Pueblo (occupied 100 years earlier than Tijeras), turkeys (with unknown genetics) are also consuming a non-maize diet in a large village without evidence for pens ${ }^{9}$ (Pugh 2010; personal communication, Christina Pugh,

\footnotetext{
${ }^{9}$ Current evidence suggests a lack of known turkey pens at both Pot Creek Pueblo and nearby Picuris Pueblo (personal communication, Patricia Crown, Christina Pugh, Severin Fowles, and Michael Adler, 2021).
} 
2021). On the Pajarito Plateau, at LA 4618 (late AD 1200s-1300s), domesticated (aHap1), maize eating turkeys are present in a small single roomblock pueblo completely lacking evidence for pens (Rawlings and Driver 2010; Schmidt 2007; Speller et al. 2010). Finally, consider the curious case of Salmon Pueblo. Here, three separate room contexts suggested the presence of pens, albeit without dung/droppings, yet analysis of eggshell indicated that turkey chicks were likely hatched in different, separate, and noncontiguous rooms from each possible pen location (Beacham and Durand 2007). In all of these cases, clear evidence for turkey pens is lacking, but genetics, isotopes, botanical, and eggshell analyses indicate that Ancestral Pueblo peoples were intricately managing these birds, nonetheless.

Using this evidence, we can now confidently disprove certain assumptions regarding turkey exploitation and penning, for example at Turkey Creek Pueblo (AD 1100-1200) where Johnson (1965: 72-73) argued, "[a]lthough there was no direct evidence for either turkey hunting or keeping in the archaeological record, the practice of hunting can be inferred from the presence of turkey bones and the absence of turkey pens or other traces of their captivity." A more accurate sentiment might state that since no aggregated dung/dropping deposits supported the clear presence of a turkey pen(s) at this site, it is likely Ancestral Pueblo peoples adapted their strategy of turkey interaction to continue exploiting turkeys (regardless of haplogroup) through non-penning management. At least until physical, genetic, isotope, or other analytical information proves otherwise.

These archaeological records help revitalize and shift our understanding of postcontact descriptions of human-turkey interaction in Pueblo villages. While ethnographic and ethnohistoric evidence supports exploitation of turkeys for feathers, it is also true that these records support a form of turkey management wherein birds are allowed to free range. It thus appears that this management approach allowed turkeys to integrate into village or household life without creating intensive human demands for their care and wellbeing. Essentially, Pueblo peoples kept turkeys on a long leash.

If we accept, as I argue here, that this form of management in turkey penning is present during the pre-contact past, then it begins to help explain the variation present in turkey pens, or lack of turkey pens, throughout the SW/NW. Turkeys were penned on a continuum depending on the restrictive characteristics and form of anthropogenically modified Pueblo spaces at distinct places and times - and likely were influenced by the ultimate flock size of kept turkeys. Pueblo peoples determined when, how, and to what degree turkey penning would occur, and often used mixed approaches, likely for variable exploitation strategies. Large turkey pens at Pindi Pueblo and Arroyo Hondo Pueblo, coupled with evidence for individual bird pens or bird tethering/ caging events, are prime examples of this approach. At Arroyo Hondo, genetic, isotope, and eggshell analyses further highlight this complexity. In Plaza $\mathrm{K}$ and associated rooms, genetic and stable isotope analysis of 12 turkeys indicate the presence of one aHap2 turkey eating a non-maize diet within a group of 11 aHap1 turkeys eating a maize diet (Conrad et al. 2016; Kemp et al. 2017). Plaza K also includes eggshells that suggest they were exploited relatively soon after being laid, and eggshells that suggest turkey chicks were allowed to hatch. While these turkey specimens all became incorporated into Plaza $\mathrm{K}$ deposits during the use or abandonment of the village, their life-history diversity speaks to variation in turkey management and penning. 
This repertoire of penning allowed flexibility in turkey management that represents an adaptive, resilient, and Indigenous approach prior to, during, and after contact. We see evidence of this during the upheaval of the contact-era. Spanish peoples introduced a variety of domesticated animals into the SW/NW (Jones 2015), but long-term flexibility in turkey penning may have facilitated a relatively seamless transition of these domesticates into Pueblo life in terms of management. For example, at Paa-ko Pueblo, north of Tijeras Pueblo in the Sandia Mountains, excavations revealed a fence and dung deposits across the central plaza dating to the colonial period, and descriptions aptly noted, "[c]onstruction of a fence across part of the plaza may seem a radical intrusion into a space normally associated with public activities and ritual, but this is the same zone allocated to penning and raising turkeys in precolonial Pueblos" (emphasis added; Gifford-Gonzalez and Sunseri 2007: 278). Turkeys were also continuously penned and exploited within rooms throughout the contact period (AD 1300-1672) at Gran Quivira (Pueblo de las Humanas; McKusick 1981). Evidently, adaptive turkey management resulted in adaptive response to the introduction of non-native domesticates.

More broadly, if North American turkey management is considered holisticallyeven though different types of turkeys and archaeological contexts exist - this flexibility in turkey penning matches patterns identified elsewhere. In eastern North America, evidence supports wild turkey exploitation through the intentional creation of agricultural spaces to draw turkeys towards Indigenous peoples for easier hunting access ( $Z$. Morris et al. 2016). Or in Mesoamerica where both turkey pens, and an absence of pens, occurs in the archaeological record (Thornton and Emery 2017), in association with modern evidence for free-ranging of turkeys (unknown types; Mallia 1999). A now famous account of turkey introduction into Mesa Verde in 1944 helps emphasize, at least a Euro-American perspective, that an adaptive strategy for penning and confining turkeys must have been required because of the annoyance of large turkey flocks easily accustomed to human interaction and intrusively interested in all aspects of human life (Pinkley 1965).

Management of turkeys through variable penning was thus a decisive, adaptive practice that facilitated long-term, successful, and reciprocal relationships between turkeys and Pueblo peoples during the pre-contact and post-contact eras. These penning adaptations allowed turkey management to continue alongside the introduction of nonnative domesticates.

\section{Future Research in Human-Turkey and Human-Bird Management}

Although the record of human-turkey management through captivity is both abundant and diverse in the SW/NW, there is an important consideration in this research that will likely impact future studies: identifying the exact processes of adaptive Ancestral Pueblo management of turkeys at locations with large turkey bone assemblages (or evidence for turkey exploitation), but a lack of turkey pens. Turkeys were undoubtedly managed by past Pueblo peoples using a variety of techniques and approaches, but in certain contexts, the lack of evidence for any clear human management is striking. For example, consider Chaco Canyon and the ancestral village of Pueblo Alto (Akins 1985, 1987). Although evidence for human-turkey interaction exists in many Chacoan villages, based primarily on turkey bones, eggshell, droppings, and/or feathers (see 
Conrad 2020), there are very few contexts which indicate the presence of a turkey pen. Based on current records, Pueblo Alto has the largest collection of turkey bones excavated and identified from a Chaco Canyon site. There are also numerous eggshell fragments present throughout site deposits. However, Pueblo Alto also lacks any clear evidence for a turkey pen - the only evidence suggesting turkey husbandry (breeding) includes several immature turkeys identified in various site contexts. There is a lack of evidence for clear human management of these birds. Akins summarized that (1987: 484) " $[\mathrm{t}]$ he lack of immatures may suggest that a large proportion of the birds were brought into the site as full-grown individuals or that they were penned somewhere in the site that was not investigated." This is a crucial point. Evidence for turkey pensturkey management - may exist at Pueblo Alto but in unexpected ways. Unexcavated deposits, turkey penning occurring elsewhere (in this location or another), or perhaps a more broadly fundamental lack of turkey pens at this village and within Chaco Canyon all may suggest a lack of turkey management through penning, or a form of adaptive human management with very little archaeological "footprint" because penning did not exist in a recognizable form (i.e., through dung/dropping deposits).

In any case, while over a century of archaeological research in the SW/NW contributes to our record of turkey management, there are likely numerous sites, or specific site contexts, with evidence for turkey pens that remain unexcavated, lack investigation, or may have produced evidence of dung/droppings that were misidentified or simply lack examination and publication. Taphonomic processes and methodological excavation and analysis strategies may also impact the preservation of evidence for turkey pens in certain contexts. Further investigation of these types of situations may help explain why sites include abundant evidence for turkeys but lack evidence for human-turkey management and penning. Future research is required to fully explore these processes, and how this relates to the adaptive strategy of turkey management that Ancestral Pueblo peoples practiced for well over a millennium.

Gaining a more holistic understanding of pre-contact human-turkey interactions, management, and site-specific conditions that affect these relationships-or our perceptions of those processes - is also crucial for future anthropological approaches that model human-bird and animal management interactions worldwide using turkeys from the SW/NW as a proxy. For example, consider Mesoamerican and SW/ NW macaw (Ara macao/Ara militaris) breeding and exploitation (or raptors and eagles; Crown 2016; Hill 2000; Schwartz et al. 2021; Somerville et al. 2010). Although macaws are known from numerous SW/NW and Mesoamerican contexts, there is still debate surrounding the specific processes of human management of these birds, and whether direct importation from Mesoamerica, local management and breeding within the SW/NW, or some combination of both processes occurred during the pre-contact era (see Schwartz et al. 2021). It is likely that a similar flexible and adaptive strategy for macaw management occurred alongside turkey management - especially since these birds often occur in tandem within archaeological sites. It is also intriguing that while Paquimé includes abundant evidence for macaw pens, as well as turkey pens, many other archaeological sites in the SW/NW lack clear evidence of distinct macaw pens even though macaws occur in Ancestral Pueblo contexts alongside turkeys and likely consumed similar diets of anthropogenically derived foods (i.e., maize; Crown 2016; Murrieta et al. 2021; Schwartz et al. 2021). 
The social and economic context of SW/NW turkey management may also provide important insight into the role of captive animal management throughout Mesoamerica, especially as it relates to evidence supporting cottontail rabbit (Sylvilagus sp.), jackrabbit (Lepus sp.), and carnivore captivity in pens and other urban contexts (Somerville et al. 2016; Somerville and Sugiyama 2021; Sugiyama et al. 2015). These animals are often identified and recovered from pen-type settings and exhibit dietary stable isotope values indicating consumption of anthropogenically derived maize, even though the purpose of their captivity and management varies (e.g., socioeconomic production versus ritual ceremonial activities — a pattern also identified in turkeys).

Recent research from northwest China also helps highlight the potential role of SW/ NW turkey evidence in modeling human-bird interactions as they relate to past human exploitation of pheasants (Phasianus sp.), red jungle fowl (Gallus gallus), and domesticated chicken (Gallus gallus domesticus). Historically, various lines of evidence suggested that northwestern China represented the earliest location of chicken domestication in East Asia and that this domestication process occurred through locally available wild red jungle fowl populations (see Peters et al. 2016 and references therein). While this is now largely disproven, there is still a long-term record of human-bird interaction in northwestern China which deserves attention, especially as it relates to SW/NW turkeys. In one site, Dadiwan, ancient DNA and stable isotope analysis indicates the presence of locally available wild pheasants, not domestic chickens or red jungle fowl (Barton et al. 2009; Barton et al. 2020). These wild pheasants consumed anthropogenic food resources (i.e., millet), but were not penned or under any clear form of human management. Simply put, the authors argue that this evidence represents a pattern of "low-level bird production" (sensu Smith 2001) where pheasants somehow accessed grain stores, or consumed plant waste material, in and around villages. Essentially, this low-level bird production/management allowed agricultural waste to be transitioned into a resource yield through human consumption of millet fed, wild, and non-penned pheasant populations. It is difficult to imagine a more pertinent cross-cultural comparison when considering human management of turkeys in the SW/NW.

Finally, as human-turkey/human-bird research continues in the SW/NW, it is important to consider and contextualize not only the role of human management, but also the social context in which human management occurred through gendered/aged roles, responsibilities, and labor activities. Previous research indicates that in this region, there is often a gender task/labor divide within Pueblo communities (Szuter 2000). This research also suggests that management and care of turkeys - as a relatively small-sized household domesticate — often functioned as a task for women and/or children (Rawlings 2006; Rawlings and Driver 2008). Pueblo stories, such as the "Turkey Girl" also help support this interpretation (see Cushing 1901; Naranjo 2008). In societies worldwide, these gendered/aged labor differences tend to occur with certain types of domesticated animals (e.g., Marshall and Weissbrod 2009; Tschopik 1951: 156). If we accept that the social context of human-turkey management included specialized roles for men, women, and children, it helps refine aspects of our understanding of human-turkey relationships in the SW/NW, especially when considering turkey-human burials (see Hill 2000; Roberts 1940: 135-136). This is an important direction of future ethnographic and archaeological investigation throughout this region. 


\section{Conclusion}

Recognizing the consistent, diverse pattern of adaptive turkey penning in the SW/NW helps provide a path towards gaining important insights into human-turkey relationships on a site-by-site, context-by-context, and human-to-turkey individual scale. It is necessary to investigate and identify turkey pens through the presence of localized dung and droppings in archaeological sites from this region, just as it continues to remain necessary to identify turkey genetics, diet, demographics, and use through analytical and contextual evidence. However, as turkey pens are identified (or not) and contextualized within Ancestral Pueblo spaces, we must shift our question away from examining whether pens are simply present or absent to something more intimate - given the presence or absence of pens at these sites and other lines of turkey evidence, what does this tell us about the adaptive turkey management strategies and human relationships with these birds at those specific places and times? Taking this approach allows for a deeper understanding of how turkey domestication ultimately occurred, as our current, earliest evidence for genetically domesticated turkeys (eating maize) appear in sites without clear evidence for pens. A record which seemingly contradicts what we expect for the earliest identified human-turkey relationships and the domestication process itself. Investigating these questions may also help us place and determine how late Pleistocene and early/mid-Holocene exploitation of turkeys in the SW/NW occurred (e.g., Akins 2006; Newbold et al. 2012) and whether the incipient stages of turkey domestication were the result of individual turkey capture and penning/caging — or more likely tethering - that is present throughout the entire Ancestral Pueblo-era in this region. Shifting our perspectives on turkey penning may also help clarify the presumed intensification of turkeys that occurred after the Basketmaker periods in the SW/NW, and whether or not this represents a true shift in turkey exploitation strategies even while turkey penning remained unchanged during this era. Expanding our perspectives on penning and management is crucial for guiding future, turkey-based research, and understanding human-bird/animal interaction and relationships worldwide.

Acknowledgments I thank and acknowledge the Indigenous peoples, lands, contexts, practices, and experiences that I write about and discuss in this paper. This paper stems from the result of a public lecture for the Crow Canyon Archaeological Center in January 2021 - thank you to Tayler Hasbrouck and Kyle Bocinsky for facilitating this event. I could not have completed this research without Hannah Van Vlack who patiently hypothesized with me about turkey pens during a global pandemic, thank you. I am extremely grateful to insights, discussions about turkeys, and early manuscript reviews provided by Bill Lipe, Robin Lyle, and Tom Windes. A large number of colleagues helped provide access to literature, photographs, and their own personal insights for this research, including Michael Adler, Matthew Barbour (and New Mexico Historic Sites), Klint Burgio-Ericson, Jamie Civitello, Allison Colborne, Jennifer Day (and the School for Advanced Research), Jonathan Dombrosky, Severin Fowles, Hayward Franklin, Phil Geib, Emily Lena Jones, Eric Kaldahl (and the Amerind Foundation), Brian Kemp, Tim Kohler, Melissa Lawton (and the Museum of Northern Arizona), Keith Lyons, Cynthia Mackey (and the Peabody Museum of Archaeology and Ethnology), Peter McKenna, Daisy Njoku, George Prothro, Christina Pugh, Curtis Quam, Gina Rappaport (and the National Anthropological Archives), Paul Reed, Barb Roth, Harry Schafer, Matthew Schamder, Camilla Speller, Nathan Sowry (and the National Museum of the American Indian), Diane Tyink (and the Maxwell Museum of Anthropology), and Jannelle Weakly (and the Arizona State Museum) - I am thankful for your time and support. Two anonymous reviewers and R.G. Matson provided extremely valuable comments that greatly contributed to this manuscript — thank you all. Thank you also to Los Alamos National Laboratory and 
Bethann McVicker for providing support, open-access funding, and GIS assistance for this research. Any errors or omissions in the text are my own.

Author Contribution Not applicable.

Funding The Los Alamos National Laboratory, Environmental Protection \& Compliance Division, Environmental Stewardship Group, provided funding for the article processing charge associated with this openaccess publication.

Data availability Not applicable.

Code availability Not applicable.

\section{Declarations}

Conflict of Interest The author declares no competing interests.

Open Access This article is licensed under a Creative Commons Attribution 4.0 International License, which permits use, sharing, adaptation, distribution and reproduction in any medium or format, as long as you give appropriate credit to the original author(s) and the source, provide a link to the Creative Commons licence, and indicate if changes were made. The images or other third party material in this article are included in the article's Creative Commons licence, unless indicated otherwise in a credit line to the material. If material is not included in the article's Creative Commons licence and your intended use is not permitted by statutory regulation or exceeds the permitted use, you will need to obtain permission directly from the copyright holder. To view a copy of this licence, visit http://creativecommons.org/licenses/by/4.0/.

\section{References}

Aasen, K. (1984). Pollen, macrofossil, and charcoal analyses of Basketmaker coprolites from Turkey Pen Ruin, Cedar Mesa, Utah. Unpublished MA Thesis, Department of Anthropology, Washington State University.

Akins, N. J. (1985). Prehistoric faunal utilization in Chaco Canyon: Basketmaker III through Pueblo III. In F. J. Mathien (Ed.), Environment and subsistence of Chaco Canyon New Mexico (pp. 305-445). National Park Service. Publications in Archeology 18E, Chaco Canyon Studies.

Akins, N. J. (1987). The faunal remains from Pueblo Alto. In F. J. Mathien \& T. C. Windes (Eds.), Investigations at the Pueblo Alto Complex Chaco Canyon New Mexico 1975-1979: volume III part 2 Artifactual and biological analyses (pp. 445-650). National Park Service. Publications in Archaeology 18F, Chaco Canyon Studies.

Akins, N. J. (2006). Archaic animal subsistence in Fresnal Canyon. In S. C. Lentz (Ed.), High rolls cave: Insectos, Burritos, Y Frajos archaic subsistence in Southern New Mexico (pp. 85-144). Office of Archaeological Studies. Archaeology Notes 345.

Altschul, J. H., \& Huber, E. K. (2000). Economics, site structure, and social organization during the Basketmaker III period: a view from the Lukachukai Valley. In P. F. Reed (Ed.), Foundations of Anasazi culture: the Basketmaker-Pueblo transition (pp. 145-160). The University of Utah Press.

Anderson, K. M. (1969). Tsegi phase technology. Unpublished PhD Dissertation, Department of Anthropology, University of Washington.

Anderson, K. M. (1971). Excavations at Betatakin and Keet Seel. Kiva, 37(1), 1-29.

Badenhorst, S., \& Driver, J. C. (2009). Faunal changes in farming communities from Basketmaker II to Pueblo III (A.D. 1-1300) in the San Juan Basin of the American Southwest. Journal of Archaeological Science, 36(9), 1832-1841.

Badenhorst, S., Lyle, R., Merewether, J., Driver, J. C., \& Ryan, S. C. (2012). The potential of osteometric data for comprehensive studies of Turkey (Meleagris gallopavo) husbandry in the American Southwest. Kiva, $78(1), 61-78$. 
Bailey, R. W. (1956). Sex determination of adult turkeys by means of dropping configuration. The Journal of Wildlife Management, 20(2), 220.

Bandelier, A. F., \& Hewett, E. L. (1973). Indians of the Rio Grande Valley. Cooper Square Publishers, Inc..

Barton, L., Newsome, S. D., Chen, F.-H., Wang, H., Guilderson, T. P., \& Bettinger, R. L. (2009). Agricultural origins and the isotopic identity of domestication in northern China. Proceedings of the National Academy of Sciences, 106(14), 5523-5528.

Barton, L., Bingham, B., Sankaranarayanan, K., Monroe, C., Thomas, A., \& Kemp, B. M. (2020). The earliest farmers of northwest China exploited grain-fed pheasants not chickens. Scientific Reports, 10(2556), 2556.

Beacham, E. B. (2006). Eggshell and the archaeological record: a developmental study of prehistoric eggshell. Unpublished MA Thesis, Department of Anthropology, Eastern New Mexico University.

Beacham, E. B., \& Durand, S. R. (2007). Eggshell and the archaeological record: new insights into turkey husbandry in the American Southwest. Journal of Archaeological Science, 34(10), 1610-1621.

Beals, R. L., Brainerd, G. W., \& Smith, W. (1945). Archaeological studies in Northeast Arizona: a report on the archaeological work of the Rainbow Bridge-Monument Valley Expedition. University of California Press.

Bedell, M. L. (2000). Late Pueblo II and Pueblo III cliff dwellings and community patterns in Grand Gulch. Unpublished MA Thesis, Department of Anthropology, Washington State University.

Beidleman, R. G. (1956). Ethnozoology of the Pueblo Indians in history times: part II birds. Southwestern Lore, $X X I I(2), 17-28$.

Bertram, J. B. (1990). Archaeofaunal Analysis, Sites LA50363, LA50364, And LA50371, Near Ambrosia Lake, McKinley County, New Mexico. In T. G. Baugh (Ed.), The Ambrosia Lake Project archaeological investigations of three small sites associated with the southern Chacoan outlier of Kin Nizhoni McKinley County, New Mexico (pp. 287-328). Complete Archaeological Service Associates.

Breitburg, E. (1988). Prehistoric New World turkey domestication: origins, developments, and consequences. Unpublished $\mathrm{PhD}$ dissertation, Department of Anthropology, Southern Illinois University at Carbondale.

Breitburg, E. (1993). The evolution of turkey domestication in the Greater Southwest and Mesoamerica. In A. I. Woosley \& J. C. Ravesloot (Eds.), Culture and Contact: Charles C. Di Peso's Gran Chichimeca (pp. 153-172). University of New Mexico Press.

Breternitz, D. A. (1969). Archaeological investigations in Turkey Cave (NA2520) Navajo National Monument, 1963. Northern Arizona Society of Science and Art, Inc. Technical Series No. 8.

Bugé, D. E. (1981). Prehistoric subsistence strategies in the Chama Region, Northern New Mexico. Report on file in the Department of Sociology and Anthropology, Occidental College.

Causey, C.E., Roth, B.J., \& Creel, D. (2018). Shake a tail feather: investigating turkey remains at the Elk Ridge Site. Poster presented at the Natural History of the Gila Symposium, Silver City, NM, February 2223, 2018.

Conrad, C., Jones, E. L., Newsome, S. D., \& Schwartz, D. W. (2016). Bone isotopes, eggshell and turkey husbandry at Arroyo Hondo Pueblo. Journal of Archaeological Science: Reports, 10, 566-574.

Conrad, C. (2020). Eggshells and gastroliths from Room 28 Turkey Husbandry at Pueblo Bonito. In P. L. Crown (Ed.), The House of the Cylinder Jars: Room 28 in Pueblo Bonito, Chaco Canyon (pp. 122-130). University of New Mexico Press.

Cordero, R. M. (2013). Final report on excavations of the Alameda School Site (LA 421): a classic period Pueblo of the Tiguex Province. The Office of Contract Archaeology, University of New Mexico.

Cordero, R. M., \& Dicks, A. M. (2010). LA 25862 Data Recovery. In P. A. Gerow (Ed.), The MAPL Western Expansion Project, Volume 3 (pp. 159-202). The Office of Contract Archaeology, University of New Mexico.

Crown, P. L. (2016). Just macaws: a review for the U.S. Southwest/Mexican Northwest. Kiva, 82(4), 331363.

Crown, P. L. (2020). The Architecture and sequence of use of Room 28. In P. L. Crown (Ed.), The House of the Cylinder Jars: Room 28 in Pueblo Bonito, Chaco Canyon (pp. 14-27). University of New Mexico Press.

Cushing, F. H. (1901). Zuñi folk tales. G.P. Putnam's Sons, The Knickerbocher Press.

Cushing, F. H. (1920). Zuñi breadstuff. Museum of the American Indian Heye Foundation.

Cushing, F. H. (1979). Zuñi: selected writings of Frank Hamilton Cushing. University of Nebraska Press.

Dean, J. S. (1967). Chronological analysis of Tsegi phase sites in Northeastern Arizona. Unpublished PhD dissertation, Department of Anthropology, University of Arizona.

Di Peso, C. C. (1974a). Casas Grandes: a fallen trading center of the Gran Chichimeca, volume 2. Northland Press. 
Di Peso, C. C. (1974b). Casas Grandes: a fallen trading center of the Gran Chichimeca, volume 4. Northland Press.

Di Peso, C. C. (1974c). Casas Grandes: a fallen trading center of the Gran Chichimeca, volume 8. Northland Press.

Dombrosky, J. (2015). The descriptive paleontology and applied ichthyoarchaeology of the Ponsipa Fauna. Unpublished MA thesis, Department of Applied Geography, University of North Texas.

Durand, K. R., \& Durand, S. R. (2006). Variation in economic and ritual fauna at Salmon Ruins. In P. F. Reed (Ed.), Thirty-fiver years of archaeological research at Salmon Ruins, New Mexico (pp. 1079-1100). Center for Desert Archaeology.

Durand, K. R., \& Durand, S. R. (2008). Animal bone from Salmon Ruins and other great houses: faunal exploitation in the Chaco world. In P. F. Reed (Ed.), Chaco's northern prodigies: Salmon, Aztec, and the ascendancy of the Middle San Juan region after A.D. 1100 (pp. 96-112). The University of Utah Press.

Durand, K. R., \& Ortega, E. (2018). Putting meat on the Puebloan table. In P. F. Reed \& G. M. Brown (Eds.), Aztec, Salmon, and the Puebloan heartland of the Middle San Juan (pp. 63-72). School for Advanced Research.

Dutton, B. P. (1938). Leyit Kin, a small house ruin, Chaco Canyon, New Mexico excavation report. University of New Mexico Press. Monographs of the School of American Research Number 7.

Emslie, S. D. (1981). Birds and prehistoric agriculture: the New Mexican pueblos. Human Ecology, 9(3), 305329.

Fewkes, J. W. (1892). A Journal of American Ethnology and Archaeology, Vol. II. The Riverside Press.

Fewkes, J. W. (1900). Property-right in eagles among the Hopi. American Anthropologist, 2(4), 690-707.

Fewkes, J. W. (1909). Antiquities of the Mesa Verde National Park Spruce-Tree House (Vol. 51). Bureau of American Ethnology, Bulletin.

Fiero, K. (1998). Balcony House: a history of a cliff dwelling, in Mesa Verde National Park, Colorado. Mesa Verde National Park.

Fothergill, B. (2012). The bird of the next dawn: the husbandry, translocation and transformation of the turkey. Unpublished PhD Dissertation, School of Archaeology and Ancient History, University of Leicester.

Fothergill, B. T. (2016). Reconstructing animal husbandry: trauma in Meleagris gallopavo (domestic turkey) ulnae from the American Southwest (c. 900-1678 CE). Journal of Archaeological Science: Reports, 10, $557-565$.

Frisbie, T. R. (1967). The excavation and interpretation of the artificial leg Basketmaker III-Pueblo I sites near Corrales, New Mexico. Unpublished MA thesis, Department of Anthropology, University of New Mexico.

Gallegos Lamero, H. (1927). The Gallegos Relation of the Rodriguez Expedition to New Mexico. El Palacio Press.

Geib, P.R., Spurr, K., \& Collette, J. (1999). Prehistory of the Northern Kayenta Anasazi Region: archaeological excavations along the Navajo Mountain Road. Final report submitted to the Navajo National Archaeological Department (No. 02-48).

Gifford-Gonzalez, D., \& Sunseri, J. U. (2007). Foodways on the frontier: animal exploitation and identity an early colonial pueblo in New Mexico. In K. Twiss (Ed.), Archaeology, food, and identity (pp. 260-287). Southern Illinois University Press.

Guernsey, S. J. (1931). Explorations in Northeastern Arizona: report on the archaeological fieldwork of 19201923. Papers of the Peabody Museum of American Archaeology and Ethnology, Harvard University, Volume XII.

Guernsey, S. J., \& Kidder, A. V. (1921). Basket-Maker Caves of Northeastern Arizona: report on the explorations, 1916-1917. Papers of the Peabody Museum of American Archaeology and Ethnology, Harvard University, Volume III.

Guiles, K., \& Ford, R. I. (1978). Paleoethnobotany of LA 70. In D. Snow (Ed.), Archaeological excavations at Pueblo del Encierro, LA 70, Cochiti Dam Salvage Project, Cochiti, New Mexico, final report 1964-1965 (pp. F1-F10). Laboratory of Anthropology. Laboratory of Anthropology Note No. 78.

Gunn, J. M. (1917). History traditions and narratives of the Queres Indians of Laguna and Acoma. Albright $\&$ Anderson.

Hammond, G. P., \& Rey, A. (1966). The rediscovery of New Mexico 1580-1594: the explorations of Chumascado, Espejo, Castaño de Sosa, Morlete, and Leyva de Donilla and Humaña. The University of New Mexico Press.

Hargrave, L. L. (1939). Bird bones from abandoned Indian dwellings in Arizona and Utah. The Condor, 41(5), 206-210. 
Hargrave, L. L. (1965). Turkey bones from Wetherill Mesa. Memoirs of the Society for American Archaeology, 19, 161-166.

Haury, E. W. (1945). Painted Cave Northeastern Arizona. Amerind Foundation, Inc. No. 3.

Henderson, J. (1914). Ethnozoology of the Tewa Indians (Vol. 56). Bureau of American Ethnology, Bulletin.

Hewett, E. L. (1909a). The excavations at Tyuonyi, New Mexico, in 1908. American Anthropologist, 11(3), $434-455$.

Hewett, E. L. (1909b). The excavations at El Rito De Los Frijoles in 1909. American Anthropologist, 11(4), 651-673.

Hewett, E. L., \& Dutton, B. P. (1945). The Pueblo Indian World: studies on the natural history of the Rio Grande Valley in relation to Pueblo Indian culture. The University of New Mexico and the School of American Research.

Hill, E. (2000). The contextual analysis of animal interments and ritual practice in Southwestern North America. Kiva, 65(4), 361-398.

Hodge, F. W. (1910). Handbook of American Indians North of Mexico, Part 2. Smithsonian Institution.

Hough, W. (1914). Culture of the ancient pueblos of the Upper Gila River Region, New Mexico and Arizona. Smithsonian Institution, United States National Museum, Bulletin 87.

Jeançon, J. A. (1923). Excavations in the Chama Valley, New Mexico. Smithsonian Institution. Bureau of American Ethnology, Bulletin No. 81.

Johnson, A. E. (1965). The development of Western Pueblo culture. Unpublished PhD Dissertation, Department of Anthropology, University of Arizona.

Jones, E. L. (2015). The 'Colombian Exchange' and landscapes of the Middle Rio Grande Valley, AD 13001900. The Holocene, 25(10), 1698-1706.

Jones, E. L., Conrad, C., Newsome, S. D., Kemp, B. M., \& Kocer, J. M. (2016). Turkeys on the fringe: variable husbandry in "marginal" areas of the prehistoric American Southwest. Journal of Archaeological Science: Reports, 10, 575-583.

Judd, N. M. (1925). Everyday life in Pueblo Bonito. The National Geographic Magazine, XLVIII(3), 227262.

Kayser, D. W. (1972). Whiskey Creek Project: archaeological highway salvage along State Highway 32 in Apache Creek Valley, Catron County, New Mexico. Laboratory of Anthropology Note No. 57.

Kellner, C. M., Schoeninger, M., Spielmann, K. A., \& Moore, K. (2010). Stable isotope data show temporal stability in diet at Pecos Pueblo and diet variation among Southwest pueblos. In M. E. Morgan (Ed.), Pecos Pueblo revisited: the biological and social context (Vol. 85, pp. 79-91). Papers of the Peabody Museum of Archaeology and Ethnology, Harvard University.

Kelly, J. C. (1934). Diary of work [Excavations of Kuaua Pueblo]. Field notes on file at Coronado Historic Site.

Kemp, B. M., Judd, K., Monroe, C., Eerkens, J. W., Hilldorfer, L., Cordray, C., Schad, R., Reams, E., Ortman, S. G., \& Kohler, T. A. (2017). Prehistoric mitochondrial DNA of domesticate animals supports a 13th century exodus from the northern US southwest. PLoS One, 12(7), e0178882.

Kidder, A. V., \& Guernsey, S. J. (1919). Archaeological explorations in Northeastern Arizona. Smithsonian Institution, Bureau of American Ethnology, Bulletin 65.

Kohler, T. A. (2012). The rise and collapse of villages in the Central Mesa Verde Region. In T. A. Kohler \& M. D. Varien (Eds.), Emergence and collapse of early villages (pp. 247-262). University of California Press.

Koons, M. L., \& Nash, S. E. (2015). Preliminary results of AMS radiocarbon dating of sandals from Tularosa Cave, NM. In L. C. Ludeman (Ed.), Collected papers from the 18th Biennial Mogollon Archaeology Conference (pp. 216-231). Friends of the Mogollon Archaeology.

Lang, R. W., \& Harris, A. H. (1984). The faunal remains from Arroyo Hondo Pueblo, New Mexico: a study in short-term subsistence change. School of American Research.

Lange, C. H. (1950). Notes on the use of turkeys by Pueblo Indians. El Palacio, 57(7), 198-203.

Lipe, W. D. (1979). Archaeological research at Turkey Pen Site [notes]. On file, Department of Anthropology, Washington State University.

Lipe, W. D., Bocinsky, R. K., Chisholm, B. S., Lyle, R., Dove, D. M., Matson, R. G., Jarvis, E., Judd, K., \& Kemp, B. M. (2016). Cultural and genetic contexts for early turkey domestication in the Northern Southwest. American Antiquity, 81(1), 97-113.

Lipe, W. D., Tushingham, S., Blinman, E., Webster, L., LaRue, C. T., Oliver-Bozeman, A., \& Till, J. (2020). Staying warm in the upland southwest: a "supply side" view of turkey feather blanket production. Journal of Archaeological Science: Reports, 34(B), 1-8.

Lyle, R. (2017a). Ritualized animal burials at Champagne Spring, part I: analysis and interpretation of burial fauna in Structure 34. Report submitted to Four Corners Research. 
Lyle, R. (2017b). Ritualized animal burials at Champagne Spring, part II: analysis and interpretation of burial fauna in Structure 37. Report submitted to Four Corners Research.

Mallia, J. G. (1999). Observations on family poultry units in parts of Central America and sustainable development opportunities. Livestock Research for Rural Development, 11(3). Retrieved July 21, 2021, from http://www.lrrd.org/lrrd11/3/mal113.htm

Manin, A., Corona-M., E., Alexander, M., Craig, A., Thornton, E.K., Yang, D.Y., Richards, M., \& Speller, C.F. (2018). Diversity of management strategies in Mesoamerican turkeys: archaeological, isotopic and genetic evidence. Royal Society Open Science 5, 171613.

Marshall, F., \& Weissbrod, L. (2009). The consequences of women's use of donkeys for pastoral flexibility: Maasai ethnoarchaeology. In G. Grupe, G. McClynn, \& J. Peters (Eds.), Tracking down the past. Ethnohistory meets archaeozoology (pp. 59-79). Marie Leidorf GmbH.

Marshall, F. B., Dobney, K., Denham, T., \& Capriles, J. M. (2015). Evaluating the roles of directed breeding and gene flow in animal domestication. Proceedings of the National Academy of Sciences, 111(17), 6153-6158.

Martin, P. S., Rinaldo, J. B., Bluhm, E., Cutler, H. C., \& Grange Jr., R. (1952). Mogollon cultural continuity and change: the stratigraphic analysis of Tularosa and Cordova caves (Vol. 40). Chicago Natural History Museum.

Matson, R. G. (2018). Turkey pen excavation (revised). Manuscript on file with the Department of Anthropology, Washington State University.

McCaffery, H., Tykot, R. H., Durand Gore, K., \& DeBoer, B. R. (2014). Stable isotopes analysis of turkey (Meleagris gallopavo) diet from Pueblo II and Pueblo III sites, Middle San Juan Region, Northwest New Mexico. American Antiquity, 79(2), 337-352.

McCaffery, H., Miller, K., \& Tykot, R. H. (2021). Paleodiet of turkeys (Meleagris gallopavo) in the early pueblo period of the Northern Southwest. Kiva., 87(2), 129-151. https://doi.org/10.1080/00231940.2021. 1891713.

McKusick, C. R. (1980). Three groups of turkeys from Southwestern archaeological sites. In K. E. Campbell (Ed.), Papers in avian paleontology honoring Hildegarde Howard (pp. 225-235). Contributions in Science of the Natural History Museum of Los Angeles County No. 330.

McKusick, C. R. (1981). The faunal remains of Las Humanas. In A. C. Hayes (Ed.), Contributions to Gran Quivira archaeology (pp. 39-56). National Park Service. Publications in Archaeology 17.

McKusick, C. R. (1986). Southwest Indian turkeys prehistory and comparative osteology. Southwest Bird Laboratory.

Meem, J. G. (1939). The Ceremonial Cave, Bandelier National Monument, Sandoval County, New Mexico (photographs, historical and descriptive data). In Historic American Building Survey. U.S. Department of the Interior, National Park Service.

Mindeleff, V. (1891). A study of pueblo architecture in Tusayan and Cibola. Bureau of Ethnology, Eighth Annual Report.

Morris, A. A. (1933). Digging in the Southwest. Doubleday, Doran and Company.

Morris, E. A. (1980). Basketmaker Caves in the Prayer Rock District, Northeastern Arizona, The Anthropological Papers of the University of Arizona, Number 35. The University of Arizona Press.

Morris, Z., White, C., Hodgetts, L., \& Longstaffe, F. (2016). Maize provisioning of Ontario Late Woodland turkeys: isotopic evidence of seasonal, cultural, spatial and temporal variation. Journal of Archaeological Science: Reports, 10, 596-606.

Muir, R. J., \& Driver, J. C. (2002). Scale of analysis and zooarchaeological interpretation: Pueblo III faunal variation in the Northern San Juan Region. Journal of Anthropological Archaeology, 21(2), 165-199.

Munro, N. D. (1994). An investigation of Anasazi turkey production in Southwestern Colorado. Unpublished MA thesis, Department of Archaeology, Simon Fraser University.

Munro, N. D. (2006). The role of the turkey in the Southwest. In D. H. Ubelaker (Ed.), Handbook of North American Indians. Volume 3, Environment, origins, and population (pp. 463-470). Smithsonian Institution.

Munro, N. D. (2011). Domestication of the turkey in the American Southwest. In B. D. Smith (Ed.), The subsistence economies of indigenous North American societies a handbook (pp. 543-555). Smithsonian Institution Scholarly Press.

Murrieta, E. G., Gilman, P. A., Plog, S., \& Kennett, D. J. (2021). An early military macaw from Cueva de Avendaños, Chihuahua. Kiva, 87(1), 1-22.

Naranjo, T. (2008). Life as movement: a tewa view of community and identity. In M. D. Varien, J. M. Potter, \& J.M. (Eds.), The social construction of communities: agency, structure, and identity in the Prehispanic Southwest (pp. 251-262). AltaMira Press. 
Newbold, B., Bocinsky, R.K., Kemp, B.M., \& Geib, P. (2011). Ancient domestic turkeys at Atlatl Rock Cave. Paper presented at the 76th Annual Meeting of the Society for American Archaeology, Sacramento, CA, March 31, 2011.

Newbold, B. A., Janetski, J. C., Bodily, M. L., \& Yoder, D. T. (2012). Early Holocene turkey (Meleagris gallopavo) remains from Southern Utah: implications for the origins of the Puebloan domestic turkey. Kiva, 78(1), 37-60.

Nordenskiöld, G. (1893). The cliff dwellers of the Mesa Verde Southwestern Colorado: their pottery and implements. P.A. Norstedt \& Söner.

Nott, B.M. (2010). Documenting domestication: molecular and palynological analysis of ancient turkey coprolites from the American Southwest. Unpublished MS Thesis, School of Biological Sciences, Washington State University.

Parsons, E. C. (1996). Pueblo Indian religion volume I. University of Nebraska Press.

Peters, J., Lebrasseur, O., Deng, H., \& Larson, G. (2016). Holocene cultural history of red jungle fowl (Gallus gallus) and its domestic descendant in East Asia. Quaternary Science Reviews, 142, 102-119.

Pinkley, J. M. (1965). The pueblos and the turkey: who domesticated whom? Memoirs of the Society for American Archaeology, 19, 70-72.

Powers, M. A. (1984). The salvage of archaeological data from Turkey Pen Ruin, Grand Gulch Primitive Area, San Juan County, Utah. San Juan County Museum Association.

Pugh, C. (2010). Turkey Management and Bison Trade at T'aitöna (Pot Creek Pueblo). Paper presented at the 75th Annual Meeting of the Society for American Archaeology, St. Louis, MO, April 17, 2010.

Quirolo, M.M. (1987). The culture history of Canyon del Muerto, Arizona: Basketmaker II-Pueblo I. Unpublished MA thesis, Department of Archaeology, Simon Fraser University.

Rawlings, T.A. (2006). Faunal analysis and meat procurement: reconstructing the sexual division of labor at Shields Pueblo, Colorado. Unpublished MA thesis, Department of Archaeology, Simon Fraser University.

Rawlings, T. A., \& Driver, J. C. (2008). Anasazi food production and gender relations. In M. F. Kemrer (Ed.), Celebrating Jane Holden Kelley and Her Work (pp. 137-156). New Mexico Archaeological Council Special Publication No. 5.

Rawlings, T. A., \& Driver, J. C. (2010). Paleodiet of domestic turkey, Shields Pueblo (5MT3807), Colorado: isotopic analysis and its implications for care of a household domesticate. Journal of Archaeological Science, 37(10), 2433-2441.

Reed, E. K. (1951). Turkeys in Southwestern archaeology. El Palacio, 58(7), 195-204.

Reed, P. F. (2000). Fundamental issues in Basketmaker archaeology. In P. F. Reed (Ed.), Foundations of Anasazi culture The Basketmaker-Pueblo transition (pp. 3-16). The University of Utah Press.

Reed, P. F. (2006). Salmon Pueblo: Room by Room. In P. F. Reed (Ed.), Thirty-fiver years of archaeological research at Salmon Ruins, New Mexico (pp. 95-244). Center for Desert Archaeology.

Roberts Jr., F. H. H. (1932). The village of the great Kivas on the Zuñi Reservation New Mexico. Bureau of American Ethnology, Bulletin Number 111.

Roberts Jr., F. H. H. (1939). Archaeological remains in the Whitewater District Eastern Arizona, part I. House types. Smithsonian Institution, Bureau of American Ethnology, Bulletin 121.

Roberts Jr., F. H. H. (1940). Archaeological remains in the Whitewater District Eastern Arizona, part II. Artifacts and burials. Smithsonian Institution, Bureau of American Ethnology, Bulletin 126.

Rohn, A. H. (1971). Mug House Mesa Verde National Park-Colorado. National Park Service, Number 7-D.

Roth, B. J. (2018). 2017 Archaeological investigations at the Elk Ridge Site (LA 79863), Mimbres Valley, Grant County, New Mexico. Report on-file with the US National Forest Service, Gila National Forest.

Russell, N. (2002). The wild side of animal domestication. Society and Animals, 10(3), 285-302.

Schaafsma, P. (1980). Indian rock art of the Southwest. School of American Research.

Schmader, M. F. (1994). Early Puebloan site structure and technological organization in the Middle Rio Grande Valley. Unpublished PhD Dissertation, Department of Anthropology, University of New Mexico.

Schmidt, K. M. (2007). Coalition period subsistence on the Pajarito Plateau. Kiva, 73(2), 155-172.

Schorger, A. W. (1961). An ancient pueblo turkey. The Auk, 78(2), 138-144.

Schorger, A. W. (1966). The wild turkey: its history and domestication. University of Oklahoma Press.

Schorger, A. W. (1970). A new subspecies of Meleagris gallopavo. The Auk, 87(1), 168-170.

Schroeder, A. H. (1955). Archaeology of Zion Park. University of Utah Press. Anthropological Papers No. 22.

Schwartz, C. W., Somerville, A. D., Nelson, B. A., \& Knudson, K. J. (2021). Investigating pre-Hispanic scarlet macaw origins through radiogenic strontium isotope analysis at Paquimé in Chihuahua, Mexico. Journal of Anthropological Archaeology, 61, 101256.

Senior, L. M., \& Pierce, L. J. (1989). Turkeys and domestication in the Southwest: implications from Homol'ovi III. Kiva, 54(3), 245-259. 
Shafer, H. J. (2003). Mimbres Archaeology at the NAN Ranch Ruin. University of New Mexico Press.

Simmons, M. (1979). History of the Pueblo-Spanish relations to 1821. In A. Ortiz (Ed.), Handbook of North American Indians, Volume 9 (pp. 178-193). Smithsonian Institution.

Smith, B. D. (2001). Low-level food production. Journal of Archaeological Research, 9(1), 1-43.

Somerville, A. D., Nelson, B. A., \& Knudson, K. J. (2010). Isotopic investigation of pre-Hispanic macaw breeding in Northwest Mexico. Journal of Anthropological Archaeology, 29(1), 125-135.

Somerville, A. D., Sugiyama, N., Manzanilla, L. R., \& Schoeninger, M. J. (2016). Animal management at the ancient metropolis of Teotihuacan, Mexico: stable isotope analysis of leporid (cottontail and jackrabbit) bone mineral. PLoS One, 11(8), e0159982.

Somerville, A. D., \& Sugiyama, N. (2021). Why were New World rabbits not domesticated? Animal Frontiers, 11(3), 62-68.

Speller, C. (2009). Investigating turkey (Meleagris gallopavo) domestication in the Southwest United States through ancient DNA analysis. Unpublished PhD Dissertation, Department of Archaeology, Simon Fraser University.

Speller, C., \& Yang, D. Y. (2016). Identifying the sex of archaeological turkey remains using ancient DNA techniques. Journal of Archaeological Science: Reports, 10, 520-525.

Speller, C. F., Kemp, B. M., Wyatt, S. D., Monroe, C., Lipe, W. D., Arndt, U. M., \& Yang, D. Y. (2010). Ancient mitochondrial DNA analysis reveals complexity of indigenous North American turkey domestication. Proceedings of the National Academy of Sciences, 107(7), 2807-2812.

Steele, L. W. (2018). Investigating the dynamic relationship between people and turkey in the Pueblo IV period: the case study of Sapa'owingeh (LA 306). Unpublished MA Thesis, Department of Anthropology, Eastern New Mexico University.

Stubbs, S. A., \& Stallings Jr., W. S. (1953). The excavation of Pindi Pueblo, New Mexico. School of American Research, Number 18.

Sugiyama, N., Somerville, A. D., \& Schoeninger, M. J. (2015). Stable isotopes and zooarchaeology at Teotihuacan, Mexico reveal earliest evidence of wild carnivore management in Mesoamerica. PLoS One, 10(9), e0135635.

Swannack Jr., J. D. (1969). Big Juniper House of Mesa Verde - Colorado. National Park Service Number 7-C.

Szuter, C. R. (2000). Gender and animals: hunting technology, ritual, and subsistence in the Greater Southwest. In P. Crown (Ed.), Women \& men in the Prehispanic Southwest: labor, power, and prestige (pp. 169-196). School for American Research.

Tarcan, C. G. (2005). Counting sheep: fauna, contact, and colonialism at Zuni Pueblo, New Mexico, A.D. 1300-1900. Unpublished PhD Dissertation, Department of Archaeology, Simon Fraser University.

Tarcan, C., \& Driver, J. C. (2010). The adoption and use of domestic animals at Zuni. In D. Campana, P. Crabtree, S. D. de France, J. Lev-Tov, \& A. Choyke (Eds.), Anthropological approaches to zooarchaeology: complexity, colonialism, and animal transformations (pp. 159-167). Oxbow Books.

Thomas, C. A. (1952). Did Utah have turkeys in 1200 A.D. Utah Fish and Game Magazine, 13(5), 5.

Thornton, E. K. (2016). Introduction to the special issue - Turkey husbandry and domestication: recent scientific advances. Journal of Archaeological Science: Reports, 10, 514-519.

Thornton, E. K., \& Emery, K. F. (2017). The uncertain origins of Mesoamerican turkey domestication. Journal of Archaeological Method and Theory, 24(2), 328-351.

Tschopik Jr., H. (1951). The Aymara of Chucuito, Peru (Vol. 44). Anthropological Papers of the American Museum of Natural History Part 2.

Wilcox, D. R., \& Haas, J. (1994). The scream of the butterfly: competition and conflict in the prehistoric Southwest. In G. J. Gumerman (Ed.), Themes in Southwest prehistory (pp. 211-238). School of American Research.

Windes, T. C. (1977). Dwellers of the Wood ("say, who are those turkeys?”): a preliminary eggshell report. Manuscript on file, Chaco Archives (C51724/Coll, 0002/042.001-56), National Park Service.

Windes, T. C. (1993). The Spadefoot Toad Site: investigations at 29SJ 629 in Marcia's Rincon and the Fajada Gap Pueblo II Community, Chaco Canyon, New Mexico, Volume 1. Reports of the Chaco Center No. 12, Branch of Cultural Research, Division of Anthropology, National Park Service.

Windes, T. C., \& McKenna, P. J. (2018). A reconnaissance of the archaeology of Sapawe, an ancestral Tewa village in the Rio Chama Valley, Northern New Mexico. In E. J. Brown, C. J. Condie, \& M. Thompson (Eds.), Two gentlemen of Chaco: papers in honor of Thomas C. Windes and Peter J. McKenna (Vol. 44, pp. 219-237). Papers of the Archaeological Society of New Mexico.

Winship, G. P. (1896). The Coronado Expedition 1540-1542. Bureau of Ethnology, Fourteenth Annual Report.

Young, G. (1980). Analysis of Faunal Remains. In L. S. Cordell (Ed.), Tijeras Canyon: analyses of the past (pp. 88-120). The Maxwell Museum of Anthropology and the University of New Mexico Press. 
Zeder, M. A. (2006). Central question in the domestication of plants and animals. Evolutionary Anthropology, 15(3), 105-117.

Zeder, M. A. (2012). The domestication of animals. Journal of Anthropological Research, 68(2), 161-190.

Zeder, M. A. (2015). Core questions in domestication research. Proceedings of the National Academy of Sciences, 112(11), 3191-3198.

Publisher's Note Springer Nature remains neutral with regard to jurisdictional claims in published maps and institutional affiliations.

\section{Affiliations}

\section{Cyler Conrad ${ }^{1,2}$}

1 Environmental Protection and Compliance, Los Alamos National Laboratory, Los Alamos, NM, USA

2 Department of Anthropology, University of New Mexico, Albuquerque, NM, USA 